\title{
LYNX SP. AT SPAIN DURING XIXTH CENTURY. A CASE OF STUDY FROM ECOHISTORY
}

\section{LYNX SP. EN ESPAÑA DURANTE EL SIGLO XIX. UN CASO DE ESTUDIO DESDE LA ECOHISTORIA}

\author{
ANTONIO VILLALPANDO MORENO \\ tonivillalpando@gmail.com \\ Universidad de Cádiz ${ }^{1}$
}

[RECIBIDO: 12/05/2020; ACEPTADO: 20/07/2020]

http://doi.org/10.25267/Riparia.2020.v6.03

\begin{abstract}
This paper is about Lynx sp. in Spain during XIXTh century from Ecohistoy. Historical studies about fauna are usually carried out from a biological perspective. Biologists understand that ancient biogeography, behavioral data, or environments are key issues for conservation biology. Therefore, they conducted studies concerning past times. Sometimes we find that these historical studies are not as productive as they should be. This happens because of the nature of the historical documents, the meaning of the language or the historical context. We get more than 300 references about Lynxes. 254 of the references are related with Lynx locations. We made a proposal for evolution of Linx population from Ecohistory. Work with historical documents It's very important for Ecohistory and future works of Conservation Biology.
\end{abstract}

KEYwORDs: Lynx pardinus, Lynx linx, Biogeography, Conservation Biology, Ecohistory.

1 Investigador Seminario Agustín de Horozco. HUM 240 - Patrimonio Histórico de Andalucía en la Antigüedad. Universidad de Cádiz. Facultad de Filosofía y Letras, Avda. Gómez Ulla s/n, 11003 Cádiz.

A. Villalpando Moreno, "Lynx sp. at Spain during XIXth Century. A case of study from Ecohistory”, RIPARIA 6 (2020), 74-150. 


\section{RESUMEN}

Este estudio trata sobre Lynx sp. en España durante el siglo XIX desde el enfoque de la Ecohistoria. Los estudios históricos sobre fauna suelen ser realizados desde un enfoque biológico. Los biólogos entienden que la antigua biogeografía, los datos sobre comportamiento o el medio ambiente son cuestiones clave para la Biología de la Conservación. Por lo tanto realizan estudios sobre tiempos pasados. En ocasiones encontramos que estos estudios históricos no son tan productivos como deberían de ser. Esto sucede por la naturaleza de los documentos históricos, el significado del lenguaje, el contexto histórico o elementos políticos. Se han obtenido más de 300 referencias sobre el lince y 254 localizaciones. Hacemos uns propuesta de la evolución histórica de la población de Lince desde la Ecohistoria. Creemos que es importante trabajar con documentación histórica, para la ecohistoria y para futuros trabajos de Biología de la Conservación.

Palabras Clave: Lynx pardinus, Lynx lynx, Biogeografía, Biología de la conservación, Ecohistoria. 


\section{Introduction}

This paper is about historical data about $\operatorname{Lyn} x s p$. at Spain in XIXTh century. We should understand that most of the historic documents are neither research made by biologist, nor an ecology work. Usually, data related to biology are part of a wide range of documents such as Land Laws, Economical Studies, Geography researches, Trip's books, Dictionaries, Hunting manual, biographies, etc. Biological research was something rare before late XIXth Century. Thus, biological data in historic documents are scarce, non usual. Only in a few cases we can find a huge amount of data. Often, they are associated with economical studies and geographical studies, which are focussed in economical development. Most of them are linked with agronomic works, where animal are economical resources (Interesting for hunting in big-game, valuable fur), or a problem for economical development of livestock (Vermin). Studies of fauna or biodiversity exist, but are not usual in historical works. In this kind of works we can find description of behaviour, occasionally linked with advices about how to kill the animal. At times, there are "researches" about the usefulness of the animal in the wild. So there are descriptions about how many rats it can eat, hence is thought to be useful for peasant.

Second issue we should understand is words used to refer an animal can change throughout time. The same animal can be named differently in different areas of the same country. It could even be named in different ways in the same area. It is easy to be confussed about animal quoted in historical documents. Hence, we should know different ways to refer same animal.

Third issue is about the meaning of language, because it can change over time. Some adjectives, nouns and verbs have different meanings in XIXth century from they do today. At this work is important the name "tigre" (Actually Tiger), "gato montés" (Actually Wild cat) and adjectives as "clavo" (pin) and

"Lynx sp. at Spain during XIXth Century. A case of study from..." 
"atigrado" (like a Tiger). Therefore, a historic dictionary becomes an important issue in any biological study.

Fourth important subject is historical context. Wars, politics, migrations or Industrial revolution are important facts that can change our way of focussing our study. There is link between population growth, economical activities or land use that can be very important when we are studying animals or forest at historical times. Therefore, Ecohistory is our theorical reference. Nonetheless, It is useful for Natural History.

The aim of the paper is to work from ecohistory in historical documents to get data that can be useful in the management of seriously endangered felidae, Lynx pardinus. Also in management of Lynx Lynx, that is at the present extinct at Spain. Therefore, the research can be used in actual studies made by biologist because is constructive, mainly in conservation biology.

\section{Methods}

A review of bibliography is the point of departure, as it must be. After that, we made a study about different ways of naming lynx at Spain. We use historical studies, biological studies and historic dictionaries. Then, we will spend time with Historical documents. Furthermore, we increase references with other contemporary works (XIXth century works). We are studying Lynx in Spain during XIXth century. Data from medieval times or similar can creates a problem of distortion in aim of study. Works from early XX century about typical lynx areas have been read and referenced in same cases. In all historic documents we collect data about animal behaviour. We have been looking for data about extinction. Also, we made a read of data into an historical context. Historical context is given when data is interpreted.

At the end we made clarification of data of interest in management of wildlife referred to Lynx sp. recovering program. 


\section{How Lynx it's called in vernacular way.}

It's called in different way during antiquity as shown Halna-Klein (1995): lynx at Pliny. Also chama, and rufus by the people of Gallia, lupus cerudrius, "forme du loup, les taches du pard", Also Isidorus of Seville, lincis, but related with the greek "likos" (Wolf). All references think that Lynx is a kind of wolf: Le bestiare di Ashmole; lincis, Libre du tresor and Bestiari di Brunetto Latini; lincis $^{2}$.

She adds about medieval times the work of Gaston Phebus, who made correction of "usual" mistakes. We can read "Toutefois, il y a diverses espèces de chats sauvages: spécialement, il y en a qui sont grands comme des léopards, et on les appelle tantôt loups-cerviers, tantôt chats-loups; et c'est mal dit, car ils ne sont ni loups-cerviers ni chats-loups. Il vaudrait mieux les appeler chats-léopards qu'autrement, car ils ont plus de traits communs avec le léopard qu'avec aucune autre bête". Jacques du Fouilloux said that: "Cerviers sont chats sauvages grands comme léopards"3.

Newspaper from XIXth century provide the following names for Lynx sp: Lobo cerval, Lince, Gato clavo, Gato Montés, "animal like Gato campesino", Pardo, Felis pardinus, gatopardo, lince pardo, pantera riojana, serval, tigre, tigre gallego, Felix lynx, and Lobo cerbal.

Other sources we can study are Historical dictionaries. We have done a study which is resumed in a Table. We have used RAEL dictionaries from XVIII, XIX, XXth centuries (See table $5)^{4}$.

2 E. Halna-KLeIn, Sur les traces du Lynx, Rev. Etudes Médiévales, 1995, № 28, 119-128.

3 E. Halna-KLein, Sur les traces..., 123.

${ }^{4}$ Real Academia Española (1734), Diccionario de la lengua castellana en la que se explica el verdadero sentido de las voces, su naturaleza y calidad, con las frases o modos de hablar, y otros proverbios y refranes y otras cosas convenientes al uso de la lengua. Tomo IV (G-N). Imprenta herederos de Francisco Hierro. Madrid. Voz Gato Montés, 33. Real Academia

"Lynx sp. at Spain during XIXth Century. A case of study from..." 
At Galicia, dictionaries from XIXth and early XXth century bestow us the words Lince=Lobo cerval. Lobo cerval =loboralaz, lobo rabaz, loberno, loboerme, lobo da gente, lobogato. Lubican = lobo recastado de perro. From Lupus+can, usual Spanish "mixto lobo", So Lubican is not correct name, but it was used for lynx ${ }^{5}$.

Lopez Seoane (1861) remarks names as Lince vulgar (Felis Lynx), Lobo cerval, serval and tigre. He refers Martín Sarmiento, who gives the name of "tigre gallego", a "kind of gato montés that is called tigre in Galicia because of its size and its marbled fur ${ }^{6}$.

Company said that Black wolf is called Llop cerver- Loup cervier by locals ${ }^{7}$. At Lynx, (Felis lynx). He refers the name Loup cervier, given by "les fourreurs"

Antonio Luís Carrión (1875) enumerated the harmful animals of Malaga Province. There are two felidae: Catus ferus o gato salvaje, for Wildcat, and Felis pardinus (Gato clavo) for pardel lynx. The data is given in a chapter entitled "apuntes de selección artificial"'?

Daniel Giraud Elliot (1883) made a review of naming for felidae, as it was a general problem for zoologist at XIXth century. Lynx pardinus have a long debate about its condition as

Española de la Lengua (1803), Diccionario de la Lengua Castellana. Compuesto por la Real Academia Española. Reducido a un tomo. Imprenta Viuda de Ibarra, Madrid. Voz Gato, 428. (RAE Usual. 1803). Real ACAdemia Española (1817), Diccionario de la lengua castellana por la Real Academia Española. Imprenta Real. Madrid. Voz Gato, 439.

5 AAVV, Vocabulario Castellano- Gallego de las Irmandades de Fala, Primera edición, Imp. Moret. La Coruña, 1933, 169-170.

6 V. Lopez SeOAne, Fauna Mastológica de Galicia o historia natural de los mamiferos de este antiguo reino, aplicada a la medicina, a la agricultura, a la industria, a las artes y el comercio, Santiago 1861. Imprenta de Manuel Mirás.

7 L. Company, Histoire naturelle de dèpartement des pyrénèes-orientales, T.3. Imp. Alzine. Perpignan, 1863, 45.

8 L. Company, Histoire naturelle..., 49.

9 Revista de Andalucía. Año II. Tomo III, Antonio Luís Carrión (Dir), Málaga, 1875, 85. 
species at XIXTh century. Since its first description there were numerous authors that consider it as new specie. Elliot says It was named Felis pardinus by Temm. (1827), Less. (1827, 1839, 1842) Fisch. (1829), Keyserl. \& Blas (1840), Blyyth (1842), Gerv. (1855), Clerm. (1859), Murray (1866), Danf. \& Alston (1877). Other names were Lyncus pardinus, by Gray (1842, 1867, 1869). Also Felis cervaria by Saunders (1869). Danford thought that animals of this specie were living at Asia Minor and Greece. Elliot tries to make the identification of felidae easier. At "Felis pardinus: the Spanish lynx" we get data like its relative frequency, the name of "gato Clavo". About the way to refers lynx, it's relevant the naming given to Lynx rufous at XIXth century. Felis rufa, the American wild cat, Bay cat, Mountain cat, Tiger cat, lynx montanus, Chat â ventre tacheté, and others. This must be seen relates with diversity in the ways of naming lynx rather that with the existence of different species. Lynx lynx is named "the European red lynx"; Felis lynx, Felis lupulina, Felis vulpinius, Felis borealis, Felis virgata, Lyncus vulgaris. Lynx lynx was not consider Felis cervaria, as the name was given to "the Siberian lynx".

Another name given in papernews is "pardo", which is adjudjed as "Felis pardinus of Oken and Temmink". It's said it is "el gato pardo de los viajeros y lobo cerval de los académicos" Gato cerval or Lince bayo are referenced as Felis rufa, from America. Lobo cerval is still at Pyrenees and it's more usual in other mountainous regions. The usual lynx at Spain is called "Lince Pardo". About this animal is said "acomete menos destrozos a los rebaños... hace cruda guerra a los cervatos, cabras monteses y otros animales parecidos. Another name is referenced: pantera riojana, which have spotted fur ${ }^{10}$.

Angel Cabrera La Torre wrote an informative tale about Felidae from Guadarrama. He says that the lynx is called lobo

${ }^{10}$ La Abeja, Barcelona, 05/ 20/ 1865, 113.

"Lynx sp. at Spain during XIXth Century. A case of study from..." 
cerval, and lubican. Talking about "gato montés" said It hunt "mouses, birds, squirrels and... young fallow deer!". Maybe, Cabrera have got news about the killing of young fallow deer by "gato montés" and he associated the name immediately with Felis sylvestris, even if fallow deer is not an usual prey for wild cat ${ }^{11}$.

Official Hunting laws says that at Spain there are Lince (Felis lynx) and El gato clavo o lobo cerval (Felix pardinus), all of them in the category of big game wild animals ${ }^{12}$.

Cabrera (1914) brings us Lobo cerval, Lince, Gato clavo, Gato cerval, Lubicán. He besides includes names in catalan as cat çerval, Loup çerver, and portugueses, Lynce, Gato cravo ${ }^{13}$.

Valverde (1963) call the animal lynx, but he includes that "los hombres del campo le suelen llamar gato serval"

C. Nores and V. M. Vazquez (1984) have the same names that Cabrera. They add asturian references such as llobu cerbal and lobu gris.

Maluquer i Sostres (1992) gives Garylup, Llop cerver, lob serber, Lleopardos, Lince. Garylup should be taken as Gatilup,

11 Alrededor del mundo, No 268, 07/21/1904, 37-38.

12 Revista Técnica de la Guardia Civil, Caza: Ley, reglamento y disposiciones oficiales dictadas hasta el día, relativas a la caza, recopilación anotada y comentada por el capitán Fernández Songel, Año II, $\mathrm{N}^{\mathrm{o}}$ 19, Dirección, Redacción y Administración Calle de Churruca nº15, Madrid, $07 / 1911$.

13 A. Cabrera, Fauna Ibérica. Mamíferos. Junta para ampliación de estudios e investigaciones científicas. Museo Nacional de Ciencias Naturales, Madrid, 1914, $207-$ 210.

https://archive.org/details/faunaibricamam00cabr/page/n251/mode/2up/search/linc $\underline{\mathrm{e}}$

14 J. A., VALVERDE, Información sobre el Lince en España, Boletín técnico. Serie cinegética, № 1 , Ministerio de Agricultura, Servicio general de Montes, Caza y Pesca fluvial, Impr. Rotaprint, 1963, 13. 
with a " $\mathrm{R}$ " handwritten using enlaced ductus, hence It is the same name that Lobogato Gallego, Gatolobo Castellano ${ }^{15}$.

Zofío, J. B. \& Vega, I. (2000) referred lobo cerval, lubicán, gato cerval, llubicán o gato clavo, lince pardo, tigre, tiguere, gato cravo, liberne, lince ${ }^{16}$.

Afterwards, Gutierrez Alva (2007) collects the names lobo cerval, gato rabón, lubicán, gato zarcillero, gato cerval, lobo cervario, lubicán, gato clavo, onça, leopardo, and Tigre in a study for Andalusia.

Some of words are non-mistakables (Lobo cerval, gato cerval, gato clavo, tigre, lince) Another vernacular name is not in these authors: Gato Montés. This one should be studied case by case, as it can be used for Felis silvestris, even for Viverra ginetta.

We will take Gato Montés as a lynx's reference when:

1. It appears as an economic resource. Lynx can be seen as a big-game hunt trophy. It became valuable animal because of its fur. It doesn't occurs with wild cat.

2. It's linked with attacks against live stoked mammals, such as sheep or goat. Example: Cabrales in Madoz. It also doesn't happens with wild cat ${ }^{17}$.

3. It's think to be dangerous for farming or big-game hunting. It doesn't occurs with Felis silvestris.

4. When animal description, colour, size, diet or weight are usual for Lynx sp. For example, Gato Montés refers a spotted felidae. The fur like a tiger, the cat kill fallow deer, the cat's size is over $100 \mathrm{~cm}$, etc.

15 J. Maluquer i Sostres, Noticia de la fauna de Catalunya $i$ dÁndorra al final del segle XVIII, Butlletí de la Institució Catalana d'Història Natural -Any: 1992, Nº 60, Secció de Zoologia, 9), 1992, 5-21.

16 J. B. Zofío, \& I. VEGA, ED, El Línce Ibérico, Editorial Debate / WWF- ADENA, Madrid, 2000, 136.

17 "varias especies de gatos monteses muy perjudiciales a los ganados"

"Lynx sp. at Spain during XIXth Century. A case of study from..." 
5. It's in an area where Lynx is quoted but there are no towns that made mention about lynx. Although Gato Montes is quoted in towns of the area where cases referenced before occurs. It happens in Pyrenees in Madoz. When we read its fauna, Lynx appears. When we read all towns in the area, Lynx is not quoted anymore. Furthermore, Gato Montes is quoted in the towns of Pyrenees in terms of points 1, 2 or 3. It happen in Navarra, where is referenced Lobo cerbal, but no village have new references. Also in Miñano (1826), where it disappear in the towns although It is quoted in Provinces (Sevilla) and mountains (like Gredos, Sierra de Béjar, Pyrenees, Guadalupe mountains...).

Example for Gato Montés as Lynx from Madoz can be seen at Table 4. General references which disappear in localities.

About Doñana, called in a text Oñana "Se ven en bastante número, el gato montés, el clavo y el cerval ó el lince. Este último se distingue por su magnitud, que llega á ser como la de un perro de presa-, por la hermosura de su piel rubia, manchada graciosamente de negro; por la ligereza de sus movimientos, por su astucia, y por el brillo penetrante de su ojo. Si tuviese la cola larga, podría tomarse por un hermoso tigre." 18 We can assimilate gato montes with gato clavo, and gato cerval with lince. This text show that people though that there were two kinds of lynxes in Doñana, but it was related with the colour of the fur and usual biggest size of animals with big spots as have been said by Gutierrez Alva.

It's outstanding the article "Valentía de un cazador", in which is related how Tomaset Cascarrilla, inhabitant of Seo de Urgel, kill a "gato montes" at Castellbó the day 29 of September (1844). It was a very aggressive animal, which fought again five dogs and

18 Revista Gaditana. Periódico popular, N ${ }^{\circ}$ 13, 01/26/1840, Imprenta de Esteban Picardo, Cádiz, 204. It was published later as R. SÁNCHEZ, Una cacería en el Coto de Oñana. publicada por Juan Perez de Guzman y Bouza, editada por Guillermo Vázquez, Madrid, 1984, (1841). 
left all of them hurt. The new is full of romanticism in its redaction. It's said that the animal even attack the hunter, who kill the fierce using his own hands after a failed gunshot. The size was huge. "nueve palmos y medio... desde las orejas a la cola". Hence an oversized $180 \mathrm{~cm}$ length if catalán palmo is used. It can be the reference of Madoz for Seo de Urgel at Monte Cogoll. We are sure it's a Gato Montés that must be taken as a lynx, maybe Lynx lynx ${ }^{19}$.

Gato montés (Actually Wild cat) used instead Lynx in Spanish is usual in historic document of America. All of them were written by Spaniard people, so they use usual word from European Spain to describe animals from America, where they found Lynxes and spotted felidae. University of Mexico dictionary of Nahuatl said that "ocotochtli should be translated as Gato Montes, Lynx roufous"20.

It happens in Fernández de Oviedo (1535) where ocotochtli is described "..es un gato montes...", even if the same autor use earlier (1522) "Gato cerval" in the work "Bestiario de Indias. Sumario de la Natural Historia de las Indias" ${ }^{21}$.

If Gonzalo Fernández lived at Madrid and his family was from Asturias, Gato montés could be used in these areas for Lynx.

Acosta (1590) talk about Gato montés, from north of México. We think it is the reference in García (1607), because he refers

${ }^{19}$ El imparcial. Diario de politica, literatura, comercio e industria, Año 3, 754, 10/13/1844, 3. ${ }^{20}$ http://www.gdn.unam.mx/termino/search?queryCreiterio $=$ ocotochtli\&modulo $=$ ter mino\&action $=$ search\&queryEnDiccionarios $\% 5 \mathrm{~B} \% 5 \mathrm{D}=0$ \&queryPartePalabra $=$ inicio $\& \mathrm{q}$ ueryBuscarEn=nahuatlGrafiaNormalizada\&queryLimiteRegistros $=50$

${ }^{21}$ G. FeRnÁNDEZ DE OvIEDO, Historia general y natural de las Indias, islas y Tierra Firme del mar Océano, Enriquecida por José Amador de los Ríos, Ed. Real Academia de la Historia, Madrid, 1852 (1535)

http://www.cervantesvirtual.com/obra/historia-general-y-natural-de-las-indias-islas-ytierrafirme-del-mar-oceano-tomo-primero-de-la-segunda-parte-segundo-de-la-obra--0/

"Lynx sp. at Spain during XIXth Century. A case of study from..." 
Acosta's work and the estructure of text is the same $e^{22}$. In a closer time Covarrubias (1611) said that "El gato montés...Es de calidad y hechura del tigre. Los gatos monteses son muy dañinos" $"$.

Clavijero (1776) said that Gato Montés are "animales comunes en America y Europa" and "los gatos monteses, que son mayores que los domésticos, son muy feroces y temibles". He also refers Ocotochtli as "un tipo de gato montés'"24.

At middle XVIIIth century the concept was used for Felis silvestris and was still in use for lynx. Dictionaries of Real Academia Española de la Lengua (RAEL) made a description of felis silvestris as Gato Montés, but the same name is use for $\operatorname{Lynx}^{25}$. At RAEL 1803 we can read about Gato de clavo "It's a kind of gato montés. En Estremadura dicen Gato Clavo. Felis silvester ${ }^{\prime 26}$. The name Gato montés become a general misunderstanding. Dictionaries included descriptions of gato montés where animal have characters both of Lynx sp. and Felis silvestris. At RAEL of 1817 It's said 'It's a kind of cat with red short tail, the body with

${ }^{22}$ G. García, Origen de los Indios del Nuevo Mundo e Indias Occidentales, Ed. CSIC, Madrid, 2005 (1607)

https://books.google.es/books?id=D gfjWyZfbkC\&pg=PA318\&lpg=PA318\&dq=jose + de + acosta $+1590+$ gato + montes\&source $=$ bl\&ots $=$ PjbEqepIgi\&sig $=$ ACfU3U1Izddja GGggQeRbMxDbhPoRO-

fcw\&hl=es\&sa $=$ X\&ved $=2$ ahUKEwjT2ZnnzJrnAhUyyoUKHU-

AA3oQ6AEwBHoECAoQAQ\# ${ }_{\mathrm{v}}=$ onepage\&q $=$ jose $\% 20 \mathrm{de} \% 20 \mathrm{acosta} \% 201590 \% 20 \mathrm{gat}$ $\mathrm{O} \% 20$ montes\&f=false

23 Sebastian de Covarrubias, Tesoro de la lengua castellana o española. Imprenta Luís Sánchez. Madrid. Voz Gato. 1611.

${ }^{24}$ Francisco Javier Clavijero, Historia Antigua de México, 1891, (1756), 22.

http://www.cervantesvirtual.com/obras/autor/clavijero-francisco-xavier-si-1731-1787$\underline{2474}$

25 Real ACAdemia Española (1734), Diccionario de la lengua castellana en la que se explica el verdadero sentido de las voces, su naturaleza y calidad, con las frases o modos de hablar, y otros proverbios y refranes y otras cosas convenientes al uso de la lengua. Tomo IV (G-N), Imprenta herederos de Francisco Hierro, Madrid. Voz Gato Montés, 33.

26 Real Academia Española de la Lengua (1803), Diccionario de la Lengua Castellana, compuesto por la Real Academia Española, reducido a un tomo, Imprenta Viuda de Ibarra, Madrid, Voz Gato, 428. 
stripes, which are three long stripes in the back and other ones spiral shape in the body" ${ }^{\prime 27}$.

Geographical dictionaries have the same problem. Miñano (1826) quoted in Sevilla "Gatos cervales o monteses". It means that at Sevilla Gato cerval and Gato montés are the same $\operatorname{animal}^{28}$.

Essentially, Gato montes is used for refer Lynx roufous at México even in papers and biological studies made by HispanoAmericans researchers. At European Spanish, Gato Montés is used for wildcat. Hence, in consequence, people at Spain are not going to use documents about Gato Montés in any case related with Lynx. Therefore, It is a problem in the study of historic documents about Lynx sp. ${ }^{29}$.

Martínez Reguera (1881) gives us, in one hand, Lince: Felix Lynx (Probably big spotted animal), In the other hand Felix pardinus $=$ Felis cervaria $=$ Lupus cervarius $=$ Felix rufa? $=$ Gato clavo $=$ Gato cerval $=$ Lobo cerval. (Probably small spotted animals). Lince de los Pirineos, maybe Lynx lynx, as a different animal. Hence, he thinks in three kinds of Lynxes in Spain ${ }^{30}$.

27 Real ACADEmia Española (1817), Diccionario de la lengua castellana por la Real Academia Española, Imprenta Real, Madrid, Voz Gato, 439.

28 Sebastian Miñano y Bedoya, Diccionario Geográfico y Estadístico de España y Portugal, Imp. Fernández Peralta, Madrid, 1826.

29 C. A. López-GonzÁlez, D. Ávila-Aguilar, \& M. F. Cruz-Torres, Abundancia del gato montés (Lynx rufus escuinapae JA Allen, 1903) en el Parque Nacional el Cimatario, Querétaro, México. Acta zoológica mexicana, 31(1), 2015, 138-140.

F. Botello, P. Illoldi-Rangel, M. Linaje \& V. SÁncheZ-Cordero. Primer registro del tigrillo (Leopardus wiedii, Schinz 1821) y del gato montés (Lynx rufus, Kerr 1792) en la Reserva de la Biosfera de Tehuacán-Cuicatlán, Oaxaca, México, Acta Zoológica Mexicana, 22 (1), 2006, 135-139.

M. A. SAlas PÁEZ, Hábitos alimenticios de la zorra, coyote y gato montés en la Sierra Tarasca. Revista Mexicana de Ciencias Forestales, 12(62), 2012.

https: / scholar.google.com/scholar?hl=es\&as sdt $=0 \% 2 \mathrm{C} 5 \&$ sciodt $=0 \% 2 \mathrm{C} 5 \&$ cites $=48$

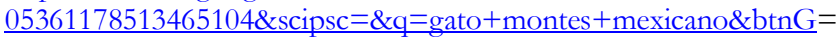

30 L. Martínez y Reguera, Fauna de Sierra Morena. Catalogo descriptivo de los mamiferos del término de Montoro, con la indicación de las utilidades y perjuicios que pueden producir al hombre, Imprenta Romero Rodríguez, Madrid, 1881, 121-123.

"Lynx sp. at Spain during XIXth Century. A case of study from..." 
About "la Hoya de Baza", which is a valley around Granada, local author says there is "lobo cerval, el lince... que en estos pueblos llaman Gato Clavo" Therefore all names are used for the same animal ${ }^{31}$.

Jose Maria de la Fuente y Morales, around 1926-1927 gave the names L. pardellus, L. pardinus, Lobo cerval, gato clavo, gato cerval $^{32}$.

Piñeiro Maceiras, J. (2013) gives us loberno, lobo rabaz, lobo serval, lobo cerval y tigre ${ }^{33}$.

Juan Jiménez, Miguel Clavero \& Abilio Reig-Ferrer (2018) give us references about historical reports of Lynxes in northeast of Spain. We have no clear that all references should be Lynx Lynx. The present paper show that name use for Lynx were very wide, confussing and there weren't popular diferences between both species, even the zoologist had no clear when the animal was a European Lynx or Pardel Lynx. It can be seen clearly at Elliot work about this issue. There is not relation between the name used and the animal described. There are references for Lobo cerval at Doñana. Also there are references from CardeñaMontoro, Baza and from Extremadura. In the north, we think that Gato Montés was usual name given for Lynxes. What's more, it could be usual traslation from catalán Llop cerver.

\section{Point of departure: old cientific research.}

Brú (1784) Show us a plate of "Gato Cerval o Lince (Also Serval, Marapute, Chat-pard Buffon, Felis pardalis, Linn. Cato pardus Mexicanus (Hernandez, Historia Mex.)". About size, it’s said "del

${ }^{31}$ La Alhambra. Periodico de ciencias, literatura y bellas artes, Serie 2, T. VI, no 2, 1840, 33. ${ }^{32} \mathrm{~J}$. CABAllero Soler, Fauna vertebrada de la provincia de Ciudad Real en el S. XX. Estudio comparativo de la obra "Catálogo sistemático de exposición faunistica de la Provincia de Ciudad Real”, Asociación cultural La Carrahila, 2017.

33J. PiÑeiro Maceiras, El lobo cerval: notas etnográficas. Argutorio: revista de la Asociación Cultural "Monte Irago", 16(30), 2013, 16-20. 
tamaño de la zorra". About its diet, It Kill "Gatos silvestres, martas, armiños y ardillas... paxaros, ciervos, gamos, liebres" ${ }^{\prime 34}$.

Royal Academy os Sciences of Spain (1804) said about "lobo cerval" that it just seems a wolf because of its howl", so it must be related with the discussion about if "lobo cerval" was canidae (wolf) or felidae (cat). It is said that generally "it have the size of a dog"35. 30 years later, It is said "El lince o lobo cerval de los manguiteros... no tiene nada de lobo" $"$.

Cook (1834) talk about lynx. He had seen animal from central Spain. Animal seems to be identical of descriptions made by Oker and Temmink Felis pardinus. He says that fur are brought to Seville, where they are sold to make jackets. He bought a good example of jacket and it was send to The Brittish Museum. He though Lynx prey mainly over rabbit and partridges. People told him about two different kind of fur, although he only saw the fur wth big spots. The vernacular name is Gato Clavo $^{37}$.

Company, L. (1863) Lynx is taken as Felis lynx. He refers the name Loup cervier, given by "les fourreurs". We get two locations, the forest of Formiguères and Salvanère ${ }^{38}$.

Martínez y Reguera (1881) refers Lynx near Montoro at Los Aserraderos, which is an area near Venta del Charco, Cardeña, and not very far from Marmolejo. He add a comentary about this issue "es más parecido al gato que al lobo, como algunos zoólogos suponen" $"$.

\footnotetext{
34 Juan Bautista Brú. Tomo I de la Colección de Animales y Monstruos del Real Gabinete de Historia Natural de Madrid, Madrid, Lam. XXVIII, 1784.

35 Memorial literario o Biblioteca periodica de Ciencias, Literatura y Artes. 06/1804, No 46, año 4, Madrid, Imprenta de Vega y C ${ }^{\mathrm{a}}, 1804,24$.

36 Semanario pintoresco español. 5/03/1837, No 49, 4.

37 S. E. CooK, Sketches in Spain during de years 1829, 30, 31 \& 32. Vol. II, 1834, 283 284.

38 L. COMPANy, (1863) Histoire naturelle... 49.

${ }^{39}$ L. Martínez y Reguera, (1881), Fauna de Sierra Morena..., 121-123.
}

"Lynx sp. at Spain during XIXth Century. A case of study from..." 
He thinks that there is a third kind of Lynx, Lince de Los Pirineos, "abunda... yo he observado el año 1865 en las cercanías de Panticosa". About Lynx behaviour he says "ocasiona destrozos en las ganaderías y haciendas, porque le gustan las cabras, ovejas, gallinas y conejos" ${ }^{40}$.

Lynx pardinus have a long debate about its condition as species at XIXth century. Since its first description, there were noumerous authors that consider it as new specie. ELLIOT (1883) made a review of data about Felidae. Its reference about "Spanish lynx" names have been quoted before. He says "the peasants of Andalusia make jackets out of the skin". Nothing it's said about diet, but the illustration shows the animal near two rabbits. The size, "nose to root of tail" is 31 inches, the tail 5 inches. Hence $78^{\prime} 74$ plus $12^{\prime} 7 \mathrm{~cm}$. Total $91^{\prime} 4 \mathrm{~cm}$. He made measurements of crane and dentition, using specimen of Brittish Museum $\mathrm{N}^{\circ}$ 1228b, from Andalusia.

Lynx Lynx is named "the European red lynx, Felis Lynx. It's said "it's rare in france". The size, "nose to root of tail" is 31 inches, the tail $93 / 4$ inches. Hence $78^{\prime} 74$ plus $24^{\prime} 8 \mathrm{~cm}$. Total $103^{\prime} 4 \mathrm{~cm}$. The tail is the difference is size with Lynx pardinus.

Lynx lynx was not considered Felis cervaria, as the name was given to "the Siberian lynx". The size of the huge lynx was "nose to root of tail" is 31 inches, the tail 5 inches. Hence 78'74 plus $12^{\prime} 7 \mathrm{~cm}$. Total $91^{\prime} 4 \mathrm{~cm}$. As small as pardel lynx. From historic perspective, we understand that some mistakes were done because of the places from where fur were taken by naturalist: Constantinople, a place where fur from all world were sells. It's quoted Danford.

At 1865, It's said that Lobo cerval is Felis Lynx. Double size of a "gato Silvestre", exactly "dos pies and 10 inches". It's

${ }^{40}$ L. MartíneZ y Reguera, (1881), Fauna de Sierra Morena..., 122. 
living at Pyrenees. It attacks fawns, near adults red deer and fallow deer.

Another name given is "pardo", which is referenced as Felis pardinus of Oken and Temmink. It's said it is "el gato pardo de los viajeros y lobo cerval de los académicos" Its referenced as inhabitant of sothern Europe and part of Asia. It's quoted that Bori de Saint-Vincent found it at Gredos ${ }^{41}$.

Unknown author said at 1876 that Lobo cerval is still at Pyrenees and it's more usual in other mountainous regions. The usual lynx at Spain is called "Lince Pardo". About this animal is said "acomete menos destrozos a los rebaños... hace cruda guerra a los cervatos, cabras monteses y otros animals parecidos". It referenced other name, pantera riojana, which have spoted fur ${ }^{42}$.

Francisco Antonio Elorza sends a fur of gato clavo to Mr. Samuel Widrington /Cook). It was taken at the area of CazallaConstantina. It's said that It is and animal abundant in Sierra Morena Mountains ${ }^{43}$.

López Seoane, V. (1861) mentions Lince vulgar (Felis Lynx). He refers Villalba and San Pedro de Orazo, both in Pontevedra. Also Sierra del Courel and "otros puntos frogosos de Galicia" He quoted Martín Sarmiento, who give the name of "tigre gallego", a "kind of gato montés that is called tigre in Galicia because of its size and its marbled fur". Description and size given is between 75 and $90 \mathrm{~cm}$, which is not very far from Pardel lynx as said Clavero \& Delibes (2013). Authors think Seoane could takes general data in Lynx description ${ }^{44}$.

${ }^{41}$ La Abeja (Barcelona) 05/ 20 / 1865, 113.

42 Las maravillas y el progreso del siglo, 10/09/1876, № 12, 6 .

43 El Corresponsal. 10/ 10/ 1842, No 1293. 4.

44 M. Clavero \& M. Delibes, Using historical accounts to set conservation baselines: the case of Lynx species in Spain. Biodiversity and conservation, 2013, vol. 22, no 8, 2013, 1691-1702.

"Lynx sp. at Spain during XIXth Century. A case of study from..." 
Malaga ${ }^{45}$.

Carrión (1875) said that Lynx attacks livestock near

Of course Chapman \& Buck (1910) give us data about Lynx at Doñana. General data for lynx is poor in this book. Just two animals are killed in a place were we already know there were lynxes. One of the animals was a "huge" male. The book is much more useful in other biological works, such as Ornithology.

\section{Historiography of Historic studies about Lynx at Spain at XIXth century.}

Studies about Historic distribution of Lynx sp. at Iberian peninsula started with Nores \& Vazquez (1984), who were the first using Madoz and other historical authors in the study of Iberian lynx in a territory: Asturias ${ }^{46}$.

About ecology, Nores \& Vázquez (1984) were thinking in behaviour of Lynx and absence of rabbit. So they conclude that about pardel lynx "habría que suponer a éste una autoecología bien diferente a la descrita actualmente en el área mediterránea, donde su presa básica es el conejo”. They quote Moguel (1804) talking about Lynx. Afterwards NORES (1999) will explain that changes in behaviour can be because of the presence of Eurasian $\operatorname{Lynx}^{47}$.

Nores \& Vasquez (1984) refer the work "Diccionario Geográfico Histórico de España, por la Real Academia de la Historia" from the year 1802. The Asturias part was handwritten by Martínez Marina, but was not published in the Dictionary. Until now It has been preserved as a manuscript. Nores and Vasquez found Lynx referenced at twelve locations: "Santa Eulalia de Oscos, Cangas del Narcea, Somiedo, Quirós, Proaza,

45 Revista de Andalucía. Año II. Tomo III, Antonio Luís Carrión (Dir.), Málaga, 1875, 85. 46 C. Nores, \& V. M.VÁzQueZ, Datos sobre la presencia del lince en Asturias desde el S. XVIII, Acta Biologica Montana, Vol. 4, 1984, 361-370.

47 C. NORES, ¿Es el lobo cerval un lince boreal (Lynx lynx)?, IV Jornadas Españolas de Conservación y Estudio de Mamíferos, Libro de resúmenes, Sociedad Española de Conservación y Estudio de Mamíferos, Segovia, 1999, 87. 
Santo Adriano, Morcín, Lena, Langreo, Parres, Caso y Llanes, at the first place it's said hay gran número" ${ }^{\text {"P8 }}$.

Nores and Vazques explain the facts that made the Lynx an extinct animal at Asturias, where Brown bear has been preserved today because of its mountains wilderness. Nores \& Vasquez thought in a dramatic decrease of lynx at early XIXth century, as they found just a reference in Madoz (Morcin). The aim of Nores study becomes to study evidences of Eurasian Lynx at northern Spain in general and its presence in Asturias in particular ${ }^{49}$.

The work of Nores can be completed with later research of J.P. Torrente \& L. Llaneza Rodríguez $(1996)^{50}$. Also with Fernandez, Ruíz de Azua \& Tejado (2003) for Gorbeia Mountains, between Vizcaya and Alava ${ }^{51}$.

Granados Corona (1987) made its Tesis, where a huge amount of data is studied in relation with climatic change, floods and vegetation, which are the main object of study. Fauna is referenced but as a poor secondary issue. This Tesis is the first work that gives us a sequence of environmental change, natural or antropics, through history in a natural reserve. The work is not the reference for studies of distribution in a wider territory. It's focussed in Doñana territory. Even if It is not important for Lynx sp., we want to quote the work as the beginning of ecohistory,

\footnotetext{
48 https://www.lne.es/asturama/2012/10/17/huellas-lince-asturias/1313244.html. https://bibliotecavirtual.asturias.es/i18n/consulta/registro.cmd?id $=2740$ 49 http://www.uniovi.es/en/-/presencia-lince-boreal-cornisa-cantabrica 50 J.P. TORRENTE \& L. LlaneZa RodrígueZ, Sobre'l llobu cerval y la so presencia n'Asturies, Asturies: Memoria encesa d'un país 2, 1996, 81-86.

51 J. M. Fernández, N. Ruiz de Azua, \& C. Tejado, Notas históricas sobre algunas especies faunísticas, Estudio faunistico del Parque Natural de Gorbeia, Fauna de Vertebrados excepto quirópteros, J.M. Fernández. (Coord), Diputación Foral de Navarra, 2003, 33-92.
}

"Lynx sp. at Spain during XIXth Century. A case of study from..." 
environmental history and the idea that using historical document can improve conservation biology ${ }^{52}$.

A. Rodríguez \& M. Delibes (1990) have the reference book for Lynx at Spain and it give us the historic distribution of Lynx for 1960. Moreover, the map about Lynx pardinus distribution is quite similar with our proposal of distribution for ninetieth century so it's a very useful work anyhow. It seems that most of extinction occurs at middle XXth century. About the present research, we can see similar pattern in the territory occupied by Lynx sp. between middle XIXth century and 1960. It's significative the presence of Lynx in Pyrenees, Galicia, north of Aragon, and mountains such as Sistema Ibérico, Sierra de San Pedro, Sierra Morena, Sistemas Béticos and Sistema Central. The main difference is that population are isolated in XXth century, so it was critical for the survival of Lynx sp.

Maluquer i Sostres (1992) adds historical references from the end of XVIIIth century and early XIX. For this reason, we include all quotes as valid for the present paper. Localities are Alt Urgell; Castellbó, Berguedà; Espinalbert, Pallars Jussà: Saroca de Bellera, Pallars Sobirá: Tirvia, Vall d’Àneu, Vall de Aran; Arròs i Vila, Viella. Vallès occidental: La Barata (Matadepedera).Also is referenced work of Lois Company, so $\mathrm{He}$ has included Formiguera and Salvanera. Last ones have been quoted by us before ${ }^{53}$.

Castells, A. \& Mayo, M. (1993) don't give us any data about old names. Theirs researches give us information about the Lynx in the ecosystem. We use this book as reference for mammals at Spain at the end of XXth century ${ }^{54}$.

52 M. Granados Corona, Transformaciones históricas del parque nacional de Doñana. Depósito Universidad de Sevilla. Tesis Doctoral inédita. 1987, 390-395 (about fauna) https://idus.us.es/handle/11441/48253

53 J. Maluquer i Sostres, Noticia de la fauna ... 5-21.

54 A. Castells, \& M. Mayo, Guía de los mamiferos en libertad de España y Portugal, Ed. Pirámide, Madrid, 1993. 
Zofío \& Vega (2000) provide us data about use of Lynx fur at XIXth century. Brehm said Lynx fur was very valuable for same country people. At early XXth century, 500 lynx furs were sold at Spain each year ${ }^{55}$.

Gragera Diaz (2000) includes data for Lynx at Extremadura during historic times. He takes account of data from Madoz at the town of Azuaga. He doesn't talk about the reference in Sierra de San Pedro, but include the area with data from earlier centuries. He made mention of Lynxes around boundaries of Extremadura, such as Candeleda (Ávila), Aroche, Cumbres de San Bartolomé, (Huelva) and Agudo (Ciudad Real). The references for Montes de Toledo around Villuercas- Ibores are very relevant $t^{56}$.

Fernández, Ruíz de Azua \& Tejado (2003) made the historical study for Gorbeia Mountains, which are between Vizcaya y Alava ${ }^{57}$. This author refers names used for lynx in northern Spain, mainly around Navarra and País Vasco. For XVIth and XVIIIth century they add names as Tigre, tiguere, onza, gato cerval, leopardo. They explain that Nores and Vasquez don't localize the word "lynx" before XIXth century because of the Science development at this moment. They collect data for XVI and XVIII century. We won't use most of these data as we work in XIXth century. At anycase we sould say that animals were quite big, and they were quoted at 1572 Bernedo, "gato cerbal", 1572 Santa Cruz de Campezo, "gato cerbal", 1597, Arrázola (Álava) "onza" at "peñas de Etxagüen de Aramayona". From this moment tiger is the usual name for Lynx, as 1762, "tigre de Arno", en Motriko 1776, monte Aránzazu, Idiazabal, 1782 Lizarza (Guipúzcoa). There is a reference as Leopard from

55 J. B. Zofío \& I. VeGA, (Eds.) El Línce Ibérico, Editorial Debate, / WWF- ADENA, Madrid, 2000, 136.

56 F. Gragera Diaz, Distribucion historica del lince iberico en Extremadura, Quercus 174, 2000, 42-45.

57 J. M. Fernández. N. Ruiz de Azua, C. Tejado, Notas históricas..., 33-92.

"Lynx sp. at Spain during XIXth Century. A case of study from..." 
1777 Lizarza. More data for tiger (Lynx sp.) came from XVIII century at sierras de Cantabria, Toloño, montes de Izquiz y Gorbeia. Author found a historical document for Gorbeia: "Decretos y ordenanzas que este Valle de Zuia pone para el gobierno cristiano y político de los vecinos, moradores y habitantes en el año de 1758". Here, fur of tiger (Lynx) is as expensive as a fur of bear ${ }^{58}$.

These authors already work with archaeozoology. There is much Quaternary evidence along Pleistocene for Lynx pardinus and lynx lynx. We prefer to focus the data for Holocene. At Pleistocene, Spain have animals like leopard, hyena, elephant, lion, rhinoceros and a large list of fauna that can't be replaced easily in Europe ${ }^{59}$.

Fernández, Ruíz de Azua \& Tejado (2003) give us the following data: "At Diccionario geográfico histórico de España (Real Academia de la Historia, 1802) se cita para Gorbeia la presencia de cuando en cuando de algunos "pequeños tigres y otras fieras no comunes en el país", referencia copiada por Miñano (1826) en los mismos términos". We get few new location of Lynx sp. that have been quoted at this paper.

Fernández, Ruíz de Azua \& Tejado (2003) add "La Junta General de Vizcaya decretó en 1818 suprimir las gratificaciones por captura de zorros, pero continuar con "las designadas a cazadores de osos, lobos, y lobos cervales, que vulgarmente se llaman tigres", ratificándose además en estos extremos en $1841 "$ " They use Madoz work. They concludes that "Madoz... "cita en Orozko la caza de "tigres pequeños... y en el caso de Gorbeia la aparición de vez en cuando de algunas onzas o pequeños tigres". There are not references of Lobo cerval for Navarra and about Lynx at Pyrenees. Also there are no references

\footnotetext{
58 Idem, 69-70.

59 Idem, 69.

${ }^{60}$ Ibidem
} 
about Gato Montes as Lynx. Authors, quoting Olavarría, 1951 says that "En 1862, la Provincia de Álava ...abatir en tiempo de nieve, entre otros animales dañinos, "algún tigre que se ha visto". Authors give data about prize payment disappearing at early XIXth century. They give us references as the last payment at Barambio in 1801 and from Urcabustaiz from 1803. ${ }^{61}$ Other references are given at Sierra Elguea $(1815)^{62}$, Trucíos (1815 y 1816) ${ }^{63}$. Authors add reference of Gorosabel (1899) for kill of Lynx at 1820 in Guipúzcoa. They understand there is a mistake in the reference of last Lynx for 1837, because they have data for another Lynx at Villanañe, Álava, sometime around $1919^{64}$.

For Andalusia, Gutierrez Alva (2007) has done a huge effort to get data about Lynx pardinus. His work includes data from medieval times until XXth century. Nevertheless, Gato montés is not included as feasible form used for lynx. He used works of noumerous naturalist from XIXth century, such as Madoz (1845), George Clark, (1850), Martínez Reguera (1881) and Graell (1897) ${ }^{65}$.

Gutiérrez Alva (2007) quoted Ramírez y las Casas-Deza (1840) who reffers "Gatos cervales" at San Calixto, near Hornachuelos. (Cordoba province) ${ }^{66}$.

Cassola (1855) call it Lince. He said they are bigger than Lynx from other areas because it has the same size that a "perro perdiguero". Gutierrez Alba (2007) says that author shows presence of Lynx at Baza Mountains. No pages are quoted, so we

${ }^{61}$ J. M. Fernández. N. Ruiz de Azua, C. Tejado, Notas históricas..., 70.

62 Idem, 71.

${ }^{6}$ Idem, 71: "documentada en Diputación Foral de Bizkaia"

64 J. M. Fernández, N. Ruiz de Azua, C. Tejado, Notas históricas..., 71. There is documents for payment in Archivo del Territorio Histórico de Álava.

65 V. GutiÉrREZ AlbA, Apuntes históricos sobre el lince ibérico en Andalucía, Galemys, 19 (2), 2007, 33-52.

66 We don't have read this book, which is preserved at Córdoba, so we add the data from Gutierrez Alba.

"Lynx sp. at Spain during XIXth Century. A case of study from..." 
include it. Later, we will show other references for this area from newspaper which are older in time ${ }^{67}$.

Author quoted other references between 1870 and 1880 from Granada province: Marquesado del Cenete, Sierras de Guadix, Lopera y Yerena. He aswell made menction of an isolated lynx that was killed at San Roque (Cadiz province) at $1913^{68}$. He also reviews the work of Collantes de Teheran. Here we think reference for Gato Montes at Moron should be taken as presence of Lynx. It's said "bigger vermin at Moron are wolf and gato montés" ${ }^{\prime 69}$.

Gutiérrez Alva (2007) includes local data such as "Premios a los matadores de animales dañinos" from Calañas (Huelva), were Lynx appear somewhere between 1818- 1861. He quoted absence of Lynx at two great works "Apuntes relativos a la aparición y extinción de animales dañinos en las provincias del Reino. 1855-1859. (Ministerio de Fomento 1861)". And also, no lynxs at "Animales dañinos extinguidos en la Península é islas adyacentes, por los cuales se abonaron premios durante el año 1864 (Junta General de Estadística1865)". We think that Gato Montés should be lynx sp. in same condition we said before.

Boy (1840) gives us key issues to understand the problem. We read "Lince: Se conoce como lobo cerval o cervario" Author gives us data about price of a Lynx fur and the conection between Lynx fur and peleteries industry. It was used for manguito dress, in France and other for other clothes in Turkey. Longest hairs, clearest and well-spotted fur were better valued.

${ }^{67} \mathrm{~J}$. B. CASSOLA, Ensayo histórico sobre la antigüedad, honores y privilegios de la muy noble y leal ciudad de Baza y pueblos de su abadía, Baza, Imprenta de P. Flores, 1855, 26.

68 V. Gutiérrez AlBA, Apuntes históricos... 38.

69 Collantes de Teran. Historia de Morón de la Frontera. Biblioteca de Estudios Moronenses, 1, Antonio Miguel Bernal y Manuel García Fernández (Ed), Fundación Fernando Villalón, Morón de la Frontera, 1990, (1840).

${ }^{70} \mathrm{~J}$. BoY, Diccionario teórico, práctico, histórico y geográfico de comercio publicado bajo los auspicios de la M. I. Junta de Comercio de Barcelona, Tomo III, Imp. de Valentín Torrás, Barcelona, 1840, Voz Lince, 677. 
The fur cost was 10-12 turkis piaster. Between 1844 and 1885, each peaster was valued in equivalence of gold, exactly $6^{\prime} 6 \mathrm{~g}$. of gold each one. That means that a Lynx fur price was 66g. $-79^{\prime} 2$ g. of gold. 100 Spanish pesetas was 32'25g. of gold. So, a Lynx fur can be selled near 200-250 pesetas. Spanish price for vernin at 1834 was 20 reales if was a Lynx, hence the fur was valued in 5 pesetas. This can help to understand why Lynx are scarce, except the less spotted fur, that we think was widely known as gato montes. Even this one is not as common as it must be. BOY (1840) says that Spanish lynx furs were selled in France ${ }^{71}$.

When Gutiérrez Alva (2007) studied Dictionary of Madoz, he found lynx at Cumbres de San Bartolomé, Aroche, Bollullos, Hinojos, and Almonte. Gutierrez Alva argues that there are no more Lynx references at Madoz, "maybe because of the informer". We believe $\mathrm{He}$ is right. Furthermore, he made mention of El Almendro, where he found relevant the existence of "other animals which are kinds of gato montes". It should be related with Lynxes. We have other quotes. Another work used by him is Tomas Lopez Dictionary where we can read "Gatos clavos, gatos cervales ... in these mountains" (Sierra Morena, Huelva).

Author read a keystone work for identify lynx at historic documents. "Una cacería en el coto oñana", written by Rafael Sánchez (1841). Work was quoted as Sánchez 1994, because he used a reedition. He uses the book for refer Lynx at Doñana. The words of Sanchez "se ven en bastante número el gato montés, el clavo y el cerval ó el lince". That sentence can be understood in the following way: Are seen in great number gato montés, (called)... clavo (¿Small spoted?) and (gato) Cerval or Lynx (¿Greater spoted animal?). Another reading could be a different animal for each one, but it is impossible at Doñana, where we are sure that all of them are the same species. Gato clavo, gato serval

${ }^{71} \mathrm{~J}$. Boy, Diccionario teórico, práctico..., 677.

"Lynx sp. at Spain during XIXth Century. A case of study from..." 
and lince are widely recognised as the same animal, hence, Lynx pardinus. It's like this because $\mathrm{He}$ is talking about Doñana at $1840^{72}$. About the original, Doñana is called in the text Oñana. Full reference is "Se ven en bastante número, el gato montés, el clavo y el cerval ó el lince. Este último se distingue por su magnitud, que llega á ser como la de un perro de presa, por la hermosura de su piel rubia, manchada graciosamente de negro; por la ligereza de sus movimientos, por su astucia, y por el brillo penetrante de su ojo. Si tuviese la cola larga, podría tomarse por un hermoso tigre"73. This text show that people though that there were two kinds of Lynxes in Spain, but usually it was related with the color of the fur and usual bigest size of animals with big spots.

Fray Juan Ruiz bestows Hinojosa del Duque, in Cordoba mountains at the year 1922. We read "del orden fieras, al lobo, zorra y gato montés; algún oso menor o tejón y más frecuentemente a urones, ginetas, fuinas y alguna otra alimaña"74. Gato Montés here could be taken as Lynx, because of the use of " ; " that makes a group of fierces.

Author referenced Martínez Reguera (1881) for Montoro, (Córdoba) at Sierra Morena: "convivían unos linces que se alimentaban de pequeños vertebrados, junto a otros de mayor tamaño (comúnmente llamados "gato clavo", "gato cerval" o "lobo cerval") muy capaces de cazar cérvidos"75. He thinks that the work gives a view of two different species at Sierra Morena. Lynx is supposed to be an animal with grey fur and spotted fur which is called Lynx, which attack livestock. Another animal, golden colour and well spotted, which are called "gato clavo", "gato cerval" o "lobo cerval" which is said to be mighty of kill

72 R. SÁnCHEZ, Una cacería ... Earlier reference from 1840 in Revista Gaditana. Periódico popular, Op. Cit. 204.

73 Revista Gaditana. Periódico popular, No 13. 01/26/1840, 204.

74 V. Gutiérrez AlbA, Apuntes históricos... 42.

75 Idem, 47. 
animal near the double in size. We work with the original of Martínez Reguera (1881) in our paper ${ }^{76}$.

In La Rioja, C. Zaldívar Ezquerro \& J. L. Gómez de Francisco (2008) provide quotes for late XIXTh century at Sierra del Moncayo, and for early XXth century at Sierra de Madero y Laguna de Cameros. They add a new name, "lobo corbato". They reference last lynx of Alava for 1834 is not correct. We quoted before the reference of Fernandez Villanañe, Álava, sometime around $1919^{77}$.

Galicia has old references by Lopez Seoane (1861), and older references by Martín Sarmiento. These have been quoted before. There is an earlier mention of Lynx in Ancares of Lugo in 1987, en Castillo de Loiras, en Valle de Vilarello. We wish to include this reference because we found a possible reference at Madoz in a close area at Santa María do Casaio, which have no sense as an isolated quote ${ }^{78}$.

Casas-Marce, M., Revilla, E., Fernandes, M., Rodríguez, A., Delibes, M., Godoy, J. A. (2012). Give a set of data very interesting for this paper, as they positioned Lynx pardinus from fur and naturalized animals placed in museum or private collection. We just know that there are near 40 animals from XIXth century until middle XXth century. Dadly, she doesn't give exact locations of them year by year, so we can't have data for a XIXTh century study. We found their method as a very

${ }^{76}$ http:/ $/$ www.bibliotecavirtualdeandalucia.es/catalogo/es/consulta/registro.cmd?id=10 $\underline{13504}$

77 C. Zaldívar EzQuerro \& J. L. Gómez de Francisco, Apuntes para la desdichada historia del oso, la cabra montés y el lince en La Rioja. Belezos: Revista de cultura popular y tradiciones de La Rioja, 6, 2008, 44-49. See 49, Last reference in Newspaper El Najerilla, $\mathrm{n}^{\mathrm{o}}$ 201, February of 1936.

78 A. P. Clevenenger, Observación de un lince ibérico (Lynx pardinus) en la provincia de Lugo, norte de España. Doñana, Acta Vertebrata 14, 1987, 140-142. (See food notes 141)

"Lynx sp. at Spain during XIXth Century. A case of study from..." 
innovative way to determinates the kind of lynx which were inhabitant in each place ${ }^{79}$.

Ciudad Real province is studied in a work by Jose María de la Fuente y Morales. (1926-1927) Data came from XIX century and early XX. Lynxes are quoted as Lynx pardinus, L. pardellus, L. Pardinus, Lobo cerval, gato clavo, gato cerval. Linxes are located at Almodovar del Campo and around it (La Viñuela, El Retamar, Calero Colection at Villarubia and Valdepeñas, Sierra Morena and Fontanosas (Finca El Peñón, 1914). Last one had a weigth of $16.500 \mathrm{~g}$ and a total size of 1,80 m. "Usual lynx's foods" are "Young deers, wild boar, hare and partridges". Author says that lynx fur is very valuable because It is used in fashionable dresses $^{80}$.

We have usual data about Lynx sp. predating over young deer, fallow deer, roe deer and livestocks. It gives us facts for the theory of "lost behaviour" and "indirect genethical selection". We understand that the most aggressive Iberian lynx preyed on ungulates, even on livestock. Hence they were persecuted because of this. The smaller, fearful, less aggressive Iberian lynx weren't hunted with the same intensity. We have this idea from the work of Guy Monfort (1954) where It's said that Lynx must be killed in Doñana when they attack young fallow deer. Over time, lynx size and agressivity could decrease ${ }^{81}$.

We gave references for France of Lynx pardinus at Formiguères and Salvanère ${ }^{82}$. There is another reference about

79 M. Casas-Marce, E. Revilla, M. Fernandes, A. Rodríguez, M. Delibes, J. A. Godoy, The Value of Hidden Scientific Resources: Preserved Animal Specimens from Private Collections and Small Museums, Bioscience, 62, 12, 2012, 1077-1082.

${ }^{80}$ WWW.lacarrahila.ecademia.edu. J. CABALLERO SOLER. Fauna vertebrada...

81 G. Monfort, Retrato de una tierra salvaje. La historia de las expediciones al Coto de Doñana. Por Guy Monfort ilustrado por Eric Hosking. Introducción del Mariscal de Campo Vizconde Alanbrooke. Diputación de Sevilla 1994 (1954). See 142 and 123.

82 L. COMPANY, Histoire naturelle ..., 49. 
Iberian Lynx at 1962 (Macizo de Carnigou) and European Lynx at 1917 at Macizo de la Neouvielle ${ }^{83}$.

Clavero, M. and Delibes M (2013) makes a huge work, in the same way that the work we were carring out in our Tesis. They get historical data, looking for to improve the environmental management. They get data from XVITh century to early XXTh century. Most of references at Miñano and Madoz are in this work. They get 154 references "pre 1900". Author found a huge number of historical researches at Vasque Country and Asturias. They also studied several authors that have referenced in our work, such as Seoane, Nores, J.M. Fernández. N. Ruiz de Azua, C. Tejado or Gutiérrez Alba. They have no data for Gato Montés, and other of our references from XIXth century, as are not in referenced studies, they are not quoted. We work with bibliography and directly with historical documents. Therefore, we get new data, which give sense to present paper. We try to prove that is not aprópiate to do a map of distribution of animals using long historical period. This is becacause of the number of animals could change a lot during different historical periods, as It seem to have been happens. Another issue is that we don't think that there is relation between names and species. Names are related with the person who is writting. Furthermore, these biologists think environmental condition in northen Spain are better for Lynx Lynx. We get data about Lynx Lynx at Panticosa (1840) and Neouvielle (1919) at central Pyrenees, where Linx pardinus was quoted at eastern areas (1968). A conservation biology program using both species of linxes could be studied. Maybe It could be interesting for Lynx pardinus when "problem animal" are detected, because Lynx pardinus seem to be bigger and more aggressive during XIXTh century. Also, Lynx have

83 M.C. SAINT Girons, Report sur la Disparition du Lynx en France, J. KratochviL History of the distribution of the Lynx in Europe. Prirodovedné prace ustavu Ceskoslovenské akademie vëd Brne, Acta sc. Nat. Brno, 2 (4), 1968, 1-50. See 15-16.

"Lynx sp. at Spain during XIXth Century. A case of study from..." 
been bringing under a huge pressure when they attack livestock or Fallow deer, as happens at Doñana. Anyway, today, Lynx pardinus have a diet based on rabit. In addition, Lynx lynx is a key specie in oceanic forest of Europe so It must be reintroduced where It disappeared due to human action (Cornisa cantábrica and Pyrenees) $)^{84}$.

We whish these authors include new references from this paper in their future research. Thus, our aim is to complement this biological research from the point of view of a historian. We tray to help in ecological management as much as we can. We wish to collaborate in conservation programs for Linx sp.

Jiménez, Clavero \& Reig-Ferrer (2018) increased the quotes looking for new locations of Lynx from North East and East of Spain. As we are looking for data for XIXTh century, we can not use all the research. There are references that we hadn't, such as Fredes (Castellón, 1888. It's said "tigre"). Another references from Catalonia could had been studied before by Maluquer i Sostres, J. 1992. References about biological data are very innovative. Northen Iberian Lynx are explained as erratic animals. They also talk about hybridization of Lynx Lynx and Lynx pardinus. Data from that paper are near references of Gato Montés from Madoz.

We think that historic studies should be done in a limited time. Imagine that in the future we have a map with references of Lynx at Spain during XXth and XXIth century. The map will show a wide distribution of Lynx, and we already know that Lynx pardinus was near extinction for long time. This is why we prefer to study Lynx sp. at XIXth century, in a geographical limit and a determined historical context. In other hand, we show at present

\footnotetext{
84 M. Clavero, M. Delibes, Using historical accounts to set conservation baselines: the case of Lynx species in Spain. Biodiversity and conservation, 2013, vol. 22, 8, 1691-1702.
} 
paper that names are not enough to make diference of lynx species in historical documents ${ }^{85}$.

\section{Data from Newspapers.}

Historic newspapers are a key issue in presen paper. We get this locations, dates and names used for Lynxes: Baza Mountains (Granada) (Lobo cerval, Lince, Gato clavo, 1840), Pirineos (Lince 1777, Lobo cerval, 1865), Castellbó- Seo de Urgel (Gato Montés, 1844), Torrelodones, (Seem Gato campesino, lobo cerval o Lince, 1865), Gredos (Pardo, Felis pardinus, gatopardo, lobo cerval, 1865), El Carbayón of Oviedo and concejos of Lena, Mieres; Quirós y Riosa, Morcín and Rivera de Arriba (Pantera, lobo cerval, 1884), El Malillo, Los Pimpollares and la Hache (Lobo cerval, 1887) Orbaiceta. (Lobo cerval o lince, 1895) CazallaConstantina (Sevilla) (gato clavo, 1842) Malaga Province (Felis pardinus, Gato clavo, 1875) Sierra del Courel (Lugo), Villalba, San Pedro de Orazo (Pontevedra) (Lobo cerval, serval, tigre. 1861 ${ }^{86}$ ), Torrejón El Rubio (Cáceres) (Lobo cerbal, lince, 1886) CasasIbañez (Albacete) (Lince o lobo cerval, 1889).

Early XXth century (Hornachuelos), El Pedroso (Sevilla) (Gato cerval, 1910), Guadarrama (Lince, 1904, ¿Gato Montés? 1904).

About "la Hoya de Baza", which is a valley around Granada, Author referred L. A. Said that in the area there is "lobo cerval, el lince... que en estos pueblos llaman Gato Clavo... mayor que un perro perdiguero". We should remember that a Spanish pointer dog from early XIXTh century was around $66 \mathrm{~cm}$ high. Today this dog is much more bigger ${ }^{87}$.

85 J. Jiménez, M. Clavero, \& A. Reig-Ferrer, New old news on the "Lobo cerval" (Lynx lynx?) in NE Spain/ Nuevas referencias antiguas sobre el lobo cerval (¿Lynx lynx?) en el NE de España. Galemys, 30, 2018, 31-36.

86 Its a resume of Seoane work at Diario de Pontevedra, 07/1865, so we always refer the original of Seoane (1861).

${ }^{87}$ La Alhambra. Periodico de ciencias, literatura y bellas artes. Serie 2, Tomo VI, n 2, 1840, 33.

"Lynx sp. at Spain during XIXth Century. A case of study from..." 
In 1777, an alive young Lynx was brought from Pyrenees to Madrid, "Se regaló al rey por el Vizconde de Carbonieres, y se llevó a la Casa de Fieras de Madrid" 88 .

José Caballero kill a "gato cerval" at "hacienda de "Ventas Quemadas" (Today El Pedroso, Sevilla) "se expuso en un local de la calle Reyes Católicos" de Jerez ${ }^{89}$.

At Hacienda "El Águila" (Hornachuelos, Córdoba) is killed "un gato cerval"".

At Doñana, 1840 "Se ven en bastante número, el gato montés, el clavo y el cerval o el lince" ${ }^{\text {"19. }}$.

Francisco Antonio Elorza send a fur of gato clavo to Mr. Samuel Widrington/Cook). It was taken at the area of CazallaConstantina. It's said that It is and animal abundant in Sierra Morena Mountains ${ }^{92}$.

Its relevan the article "Valentía de un cazador", in which is related how Tomaset Cascarrilla, inhabitant of Seo de Urgel, kills a "gato montes" at Castellbó the day 29 of September (1844). We are sure it must be taken as a Lynx ${ }^{93}$.

It's referenced a spectacle named "Fiars fight" between a "lobo cerval" and several mastiff dogs. Hence, Lynx sp. could be moved by humans from northen places to southern territories and vice versa ${ }^{94}$.

88 Mercurio histórico y político, Madrid, Imprenta Real de la Gazeta, 8/1777, 319.

${ }^{89}$ El Guadalete: Periódico político y literario, Año LVI, No 17548, 09/28/1910, 9.

${ }^{90}$ La Publicidad: Diario de avisos, noticias y telegramas, eco fiel de la opinión y verdadero trasmisor de los intereses morales y materiales de Granada y su provincia, Año XXXIV, No 9350, $01 / 24 / 1914,3$.

${ }^{91}$ Revista Gaditana. Periódico popular, 1840, 204.

92 El Corresponsal, 10/ 10/ 1842, No 1293, 4.

93 El imparcial. Diario de política, literatura, comercio e industria, Año 3, No 754, 10/13/1844, 3.

94 La España. Madrid, No 991, 05/ 27/1851, 4, Also at the newspaper La Corona, Barcelona, 31/08/1864. 
At 1865, the hunter Mariano Sánchez kill at Torrelodones (Madrid) an animal unknown, "un bicho parecido a un gato campesino, tiene bastante cuerpo, opinan que es un lobo cerval o lince, bastante dañino para el Ganado lanar"'95.

Papernews from 1865 said that Lobo cerval is Felis Lynx. It's living at Pyrenees. It's said that Bori de Saint-Vincent found a Felis pardinus at Gredos ${ }^{96}$.

At 1876, it's said that Lobo cerval is still at Pyrenees, and it's more usual in other mountainous regions. The usual lynx at Spain is called "Lince Pardo". About this animal is said "acomete menos destrozos a los rebaños... hace cruda Guerra a los cervatos, cabras monteses y otros animals parecidos. It referenced other name, pantera riojana, which have spoted fur ${ }^{97}$.

From 1884, An animal is still atacking livestock in concejos of Lena, Mieres; Quirós y Riosa, Morcín and Rivera de Arriba. It was related with a pantera... hyena.... Or lobo cerval. It kill "reses" and eat just the entrails They refers diary El Carbayón of Oviedo ${ }^{98}$.

At 1887, Juan Palacios shoot a Lobo Cerval, somewhere near El Malillo, Los Pimpollares and la Hache, all of them at Ibores Mountains. It's referenced Navalmoral de la Mata ${ }^{99}$.

At Casa Ibañez (Albacete) hunters killed a huge lince o lobo cerbal, that measured $1^{\prime} 75 \mathrm{~cm}^{100}$.

At Esterenzubí (San Sebastian) people wrottes about a wild fiar was found at Orbaiceta. It's not a wolf. It seems that the anmal have a very big head and its color looks like red, with

\footnotetext{
95 El Pabellón Nacional, Madrid, 20/05/1865, 8.

96 La Abeja, Barcelona, 20/ 05/ 1865, 113.

${ }^{97}$ Las maravillas y el progreso del siglo, No 12, 10/09/1876, 6.

98 La Unión, Madrid, Año III, No 848, 25/ 10/ 1884.

${ }^{99}$ La Época, Año XXXIX, No 12394, 23/01/1887, 2.

100 La Vanguardia, Barcelona, 11/18/ 1889, 2.
}

"Lynx sp. at Spain during XIXth Century. A case of study from..." 
marks in the back. It's supposed to be a Lobo cerval or Lince, "de la familia de los felis o gatos"101.

Lynx's size was measured as big game trophy. Animal dead have back legs tied from a stick placed high. Animal is extended and front legs give us maximum size. Hence we can get $1^{\prime} 80 \mathrm{~cm}$ animals. Lynx's size is compared with dogs. They were much smaller at XIXth century. Perdiguero español and Perro de presa were near $62-68 \mathrm{~cm}$.

\section{Remains from archaeological sites.}

All reference for Lynx sp at southern Iberia during Holocene are for Lynx pardinus. It occurs at Los Millares (Almeria) ${ }^{102}$, Los Castillejos (Granada) ${ }^{103}$, Carcaixent (Valencia) ${ }^{104}$, even in Nasri sites (XIVth century) at Antequera ${ }^{105}$. Special mention should be done for the work of Benito, from 2017, as it shows a relatively important rol of lynx as a totemic specie. There is a significant use of Lynx bones related to tool making and decorative elements. Teeth are used as an ornament. His work shows the use of $\operatorname{Lynx} \operatorname{Lynx}$ at northern Spain and Lynx pardinus at southern Spain and Portugal ${ }^{106}$. We can gather a huge set of data,

101 El Correo Español. Diario Tradicionalista, Año VIII, No 2195, 28/12/1895.

102 E. NAvas, J.A. Esquivel \& F. Molina, Butchering patterns and spatial distribution of faunal animal remains consumed at the Los Millares chalcolithic settlement (Santa Fe de Mondújar, Almería, Spain), Oxford Journal of Archaeology, 27(4), 2008, 325-339.

103 M. Altamirano García, Not only bones. Hard animal tissues as a source of raw material in 3rd millenium BC south-eastern Iberia, Menga: Revista de prehistoria de Andalucía, 5, 2014, 43-67.

104 O. García Puchol, F. Cotino Villa, C. Miret Estruch, J. L. Pascual Benito, S. B. McClure, L. Molina Balaguer, \& B. Culleton, Cavidades de uso funerario durante el Neolítico final/Calcolítico en el territorio valenciano: trabajos arqueológicos en Avenc dels Dos Forats o Cova del Monedero (Carcaixent, Valencia), Archivo de Prehistoria Levantina, 2010, 28.

105 M. Alonso Valladares \& J. A. Garrido García, La explotación de los recursos cárnicos en la frontera del Reino Nazarí de Granada.: Un estudio de caso en el yacimiento de La Moraleda (Antequera, Málaga), Revista del Centro de Estudios Históricos de Granada y su Reino, (27), 2015, 21-39.

106 J. L. PAscual Benito, Industria ósea sobre huesos y dientes de lince en la prehistoria de la Península Ibérica, In Interaccions entre felins $i$ bumans: bomenatge a Innocenci Sarrión Montañana, Museu de Prehistòria de València, 2017, 189-212. 
but is not our aim. We use data from bibliography. It shows that Lynx lynx and Lynx pardinus were living at same places (Northern Spain) during long time. Lynx pardinus is supposed to have wider distribution, even in France, during hot stages. At glatial stage, it can be placed to Southern Iberian Peninsula. It have been proved that around Gibraltar Strait there was an ecological refuge from middle Pleistocene even during glacial stages ${ }^{107}$.

Holocene remains of southern archaeological sites are linked with Lynx pardinus, hence we have been looking for bibliography about coexistence of Lynx lynx and Lynx pardinus during Holocene. We found data from northern Spain at the work Rodríguez Varela et alii $2016^{108}$.

Northern Spain is usually rich in Lynx sp. remains at archaeological sites, meanly for Pleistocene. For Holocene, Lynx pardinus remains at archaeological sites of northen Spain are founds in Urratxa III (Vizcaya, Spain), Chaves (Huesca, Spain), Portalón (Burgos, Spain), Peña del Moro (Barcelona, Spain), Balma de l'Espluga (Gerona, Spain) and Can Sadurní (Barcelona, Spain) ${ }^{109}$.

Rodríguez Varela et alii (2016) give us a huge set of data about Lynx Lynx, which includes differen references at northen península and very wide set of datation along the holocene. They think Eurasian lynx cames to Spain sometime around Younger Dryass event. They quote Coulet des Roches (Pyrenees, France), Cueva de los Cinchos, (Asturias, Spain), Pozu'del Lince in Sierra

107 J. S. Carrión, C. Finlayson, S. Fernández, G. Finlayson, E. Allué, J. A. LópezSÁEZ, \& P. GONZÁLEZ-SAMPÉRIZ, A coastal reservoir of biodiversity for Upper Pleistocene human populations: palaeoecological investigations in Gorham's Cave (Gibraltar) in the context of the Iberian Peninsula, Quaternary Science Reviews, 27(23-24), 2008, 2118-2135.

108 R. Rodríguez -Varela, N. García, C. Nores, D. Alvarez-Lao, R. Barnett, J. L. Arsuaga \& C. VAldiosera, Ancient DNA reveals past existence of Eurasian lynx in Spain, Journal of Zoology 2016, vol. 298, no 2, The Zoological Society of London, 2016, 94-102.

109 Idem, 98-101.

"Lynx sp. at Spain during XIXth Century. A case of study from..." 
de Sueve (Asturias,Spain), Rascaño (Cantabria, Spain), Serpenteko (Navarra, Spain) y Sima Pagolusieta (Vizcaya, Spain) ${ }^{110}$.

\section{New data about lynx from Historical Dictionaries from XIXth century.}

We use three works that are key sources for environmental studies os Spain during XIXTh century. First one, Real Academia de la Historia (1802) give us 18 references of felidae that may well be Lynx sp. ${ }^{111}$.

Second one, Miñano (1826), where we find 39 references for felidae, 36 could be Lynx sp. ${ }^{112}$.

The last one, but first in relevance, is usually called Diccionario Madoz. Madoz, (1845). Here we find 73 references, all of them, but three, could be Lynx sp. Just in Dictionaries we have got 124 quotes about Lynx sp. ${ }^{113}$.

Some of the data are not new. They have been referenced in bibliography shown before. Anyway, here we add references that are not in bibliography. It happens with usual names (Lince, lobo cerval, gato cerval, tigre...) and non usual in bibliography, meanly gato montés.

Data for dictionaries are resumed in tables.

110 R. Rodríguez -Varela, N. García, C. Nores, D. Alvarez-Lao, R. Barnett, J. L. Arsuaga \& C. Valdiosera, Ancient DNA..., RadioCarbon Dates. Years BP. Coulet des Roches (Pyrenees, France) 8171-8000, Coulet des Roches (Pyrenees, France), 75647431, Cueva de los Cinchos (Asturias, Spain) 1864-1639, Pozu'l Lince in Sierra de Sueve (Asturias,Spain) 4829-4581, Rascaño (Cantabria, Spain) 12082-11753, Serpenteko (Navarra, Spain) four remais . Trhe dates: 10696-10443, 3032-2855 and 505-319 (Between XVth and XVIIth century) and Sima Pagolusieta (Vizcaya, Spain), 3067-2878. 111 Real Academia de la Historia, Diccionario Geográfico Histórico de España, por la Real Academia de la Historia. Imp. Academia. Madrid 1802.

112 S. Miñano y Bedoya, Diccionario Geográfico y Estadístico de España y Portugal. Im. Pierad - Peralta. Madrid 1826.

113 P. Madoz, Diccionario Geográfico- Estadístico- Histórico de España y sus posesiones de ultramar, Imp. Madoz y Sagasti. Madrid 1854. 
Real Academia de la Historia (1802). (See resume at Table 1); Miñano (1826). (See resume at table 2); Madoz (1845). (See Resume in Table 3).

\section{Ecohistory: how to improbe knowledge about Lynx s. at Spain.}

Historical studies should be taken with three key issues. First one, it must be placed in a geographical territory. Second one, it must be done in a defined space of time. Third one, data have no sense without historical context.

Density of data in a region is related with number of academical research, knowledge of inhabitants, aim of academical studies, etc. Jaén, where Lynx have strongest population today, have no data from historical times, hence Information is scarced. Data about environment is a key issue for biology of conservation. Madoz and Miñano give us data about the forest and human activities in the area. Maybe It's a key issue for future studies. We sould understand what happened in the environment where Lynx was living and today It's extinct.

About Lynx's preys, historical data demonstrate there are environmental changes in northen región. Red deer was extremely rare. Even if there were Red deer, usual size was much smaller than today. Before the law of Isabel II, was very unusual the management of forest for increase Big Game Prizes. This is why the size of animals have been increased again and again from early XXTh century. Red deer and Wild boar seems to be much more usual today than at the end of XIXth century. Roe deer was widely decreased, and Capra pirenaica and most of the Chamois population becames extinct in several areas. There are huge changes in landscape and human activities in northen areas describes in Miñano, and Madoz. Also, there are places where actual environment is better preserved today than in Madoz times. Other Issue is decreasing of sheep and goats. Martinez Reguera says that at 1870 Spain have around 22500000 sheeps

"Lynx sp. at Spain during XIXth Century. A case of study from..." 
and 4500000 goats. Today, there are 15800000 sheeps and 2800000 goats.

We have no data about the ecology of Lynx and Wolf living in the same area. It was the usual issue at XIXth century Spain, even in the southern región of Andalusia and Extremadura. The northen forest were the home of Brown bear, Iberian Wolf and Lynx Sp. (Lynx Lynx and Lynx pardinus). Most of references of Lynx are connected with Wolf.

The name used for design Lynx is linked with, in one hand, the studies of the writter, and in the other hand, with regional designation for the animal, which are sometimes very located. We don't have data that give us doubtless quotes about what kind of lynx is referenced. Even zoologist from XIXTh century have confusing information. Differences between Lynx Lynx and Lynx pardinus were not widely recognized. It happens in Elliot, Cabrera, or Seoane.

Each school of Biology use to have a focus of studies. Aragon naturalists were a huge acount of cientific researchers that were working at issues as American fauna or, mainly, in botanic research. It's clear there is absence of data about Lynx sp. for Aragon. Also, It is obvious that numbers of botanical researches from Aragón are huge if they are compared with other territories. (Monserrat Recover, Pedro. 1980). Perhaps, nobody studied the Lynx at Aragón. Maybe, animals were very scarce since the beginning XVIIth century due to harassment made by furriers from Zaragoza ${ }^{114}$.

Historical documents can provide us with data to stablish periods of regression or increase in fauna population. The reference is the paper of Molinier\& Molinier - Meyer, (1981). We can see how the wolves decrease at1790-1801, there was a huge

114 P. Monserrat Recover, Estado Actual de los studios sobre flora de Aragón, In Flora y fauna aragonesas, II Jornadas sobre el estado actual de los estudios sobre Aragón, Huesca, 19-21 Diciembre 1979, Vol. II, Zaragoza, 1980, 879-896. 
increase between 1809-1818, wich is related with the Napoleonic wars. Also, the model of "border effect", in the text is called "fenomene frontier" that increased the number of wolf in this kind of territories of France, where human pressure was lower and livestocks were usual economical activity. It could be useful for studies about Lynx at Spain ${ }^{115}$.

We can do the following proposal of size of Lynx population in Spain over time from XIVTh century, according with historical context:

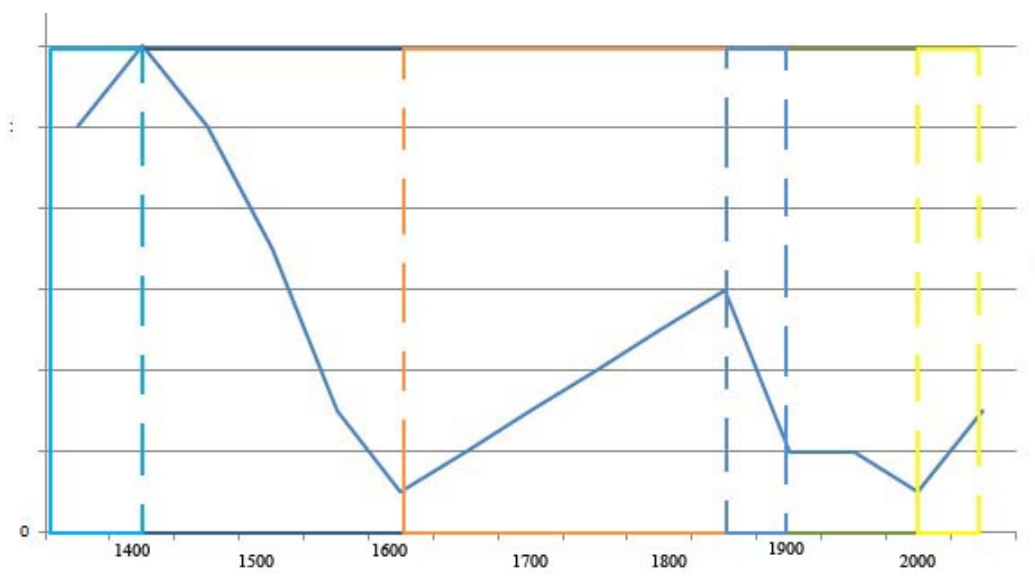

Graphic 1. Relative abundance of Lynx 1350-2020 at Spain.

Abundance of Lynxes can be studied in historical context of each period. Therefore, we don't have absolute number of individuals, but we can say if social conditions and environment was good or bad for Lynx sp'population.

First stage; clear blue. It shows potential growth of population of Linx sp at XIVTh century. At this time human population decressed because of the Bubonic Plague, climatic

\footnotetext{
115 A. Molinier, N. Molinier-Meyer, Environment et Historie: les loups et l'homme en France, Revue d'historie moderne et contemporaine, tome 28, № 2, Avril juin 1981, 1981, 225-245. See 238.
}

"Lynx sp. at Spain during XIXth Century. A case of study from..." 
changes decressed peasants because of the famine. Losses of crops were usual, so most of population migrates to urban centers. Hence, environmental condition becomes better, human pressure decreased and forest was enlarged widely. The territory were full of borderlines, were forest and "dehesa" were usual economical activities. Livestocks were prevalent. A huge number of sheep was widely distribute in Castille because of the action of "Honrado Consejo de la Mesta". The long movement of this livestock cross Spain from Extremadura to Asturias. It could be a key issue to understand presence on Lynx sp. at Northen mountains.

Second stage is marked in black. From 1400 to 1600. There is a progressive decrease in Lynx population, even at the point of a near extinction situation. It can be related with increasing of population and farming activities, mainly since 1492, which is the end of war against Kingdom of Granada. For this reason, deforestation and human pressure were increased. Borderline disappeared at this time in most of territory. There was direct harassment of Lynxes due to the value of its fur. Furs of Lynxes were widely selled in Zaragoza in XVth century. It can be useful to understand smaller abundance of Lynx sp. in Ebro basin and Aragon. XVIth century becames the stage were Lynx fur became an extraordinary valuable object. There are huge number of portrait from XVIth century, where kings and aristocracy people are wearing Lynx fur clothes. We think there were a huge pursuit of Lynxes and it could explains why Lynx is very scarce in XVIIth century ${ }^{116}$.

116 From Spain: Museo del Prado (Spain) No P001136, Coello, El Príncipe Don Cárlos. 1555-1559. Madrid.; Museo del Prado (Spain) No P001140, ¿Coello? ¿Sofonisba Anguissola?, Dama desconocida, 1567-1570. Madrid.; Museo del Prado (Spain) $\mathrm{N}^{\mathrm{o}}$ P001339, Yañez de la Almedina, San Damián, circa 1510; Museo del Prado (Spain) $\mathrm{N}^{\mathrm{o}}$ P002918, Bartolome González. Felipe III Rey de España, sedente. Circa 1615. Madrid.; Pollok House art's collection (Glasgow, Scotland, UK). Lady in a fur wrap, Coello? Sofonisba Anguissola?, 1577-1579, Made near Madrid.; National gallery, Washington, Michel Sittow, Portrait of Diego de Guevara, 1515. Portrait made in 
Third stage is marked in orange. From 1600 to 1850 . Its a period that begins with another climate crisis for farmers. Furthermore, the Spanish Empire put pressure on the population, as it was fighting in sucessive wars around the world. Human population declined or growth slows. Wars occur in the Iberian Península, mainly at 1700-1705, Napoleonic wars (Spanish Independence war 1808-1814). Revolutionary Period (1820-1823) and Carlist wars through XIXth century, mainly the periods 18331840, 1846-1849, 1872-1875. Hence, the field becomes a dangerous place, and the farmer activities decreased during war stages. In this context, Lynxes could increase, as It happens in France with the wolf. At XVIIIth century farmland increased, but at the beginning it could be beneficial for Lynx sp because ecosystem was enriched with mosaic-like landscapes. Lynx references progressively increased trough this stage. They are very

Gante.; Real Monasterio de El Escorial, Seisenegger, Portrait of Charles V, early XVIth. It's supposed to be made in Spain. From aoutside of Spain: Museo del Prado (Spain) No P000279, Parmigianino, Pedro María Rossi, conde de San Segundo, 1535-1538; Museo del Prado (Spain) No P000451, Anónimo (copia de un Tiziano). Marquesa de Mantua, XVI-XVII Original of 1534-36. At Viena: Kunsthistorisches Museum; Museo del Prado (Spain) No Museo del Prado (Spain) No P002132, Rembrandt, Judith en el banquete de Holofernes, 1634; Pinacoteca di Brera, Milán, Italy. Moroni, Portrait of G. Navagero, 1565; Portrait of Girolamo Fracastoro, Titian, National Gallery of Arts. London, UK.; National Gallery of Arts. London, UK. NG 299, Alessandro Bomvicino, Il Moretto, Portrait of a Young man. 1540-1545; Gallería Pallatina, Florence. Veronese. Portrait of a Gentleman in a fur. 1550-1560; The Frick Collection; Legado de Henry Clay Frick, Portrait of a man with red cap. Tiziano. 1510; Kunsthistorisches Museum, Viena: $N^{\circ}$ 6079, Joos van Cleve, Eleanora, Queen of France, ca. 1530. Oleo sobre roble; Hans Holbein el Joven (alemán, 1497-1543). Los embajadores, 1533. Óleo sobre roble; 207 x 209,5 cm. Londres: National Gallery, NG1314; Artista desconocido (angloholandés). Thomas Wentworth, primer barón Wentworth, ca. 1547-50. Óleo sobre tabla; $77,1 \times 73,4 \mathrm{~cm}(303 / 8 \times 28$ 7/8 pulgadas). Londres: National Portrait Gallery, NPG 1851; Moretto da Brescia (italiano, 1498-1554). Retrato del conde Fortunato Martinengo , ca. 1540-45. Óleo sobre lienzo; 114 x 94,4 cm. Londres: National Gallery, NG299; William Scrots (activo 1537-53). Eduardo VI (1537-53), ca. 1546-47. Óleo sobre tabla; 107,2 x $82 \mathrm{~cm}$. Castillo de Windsor, RCIN 404441; Paolo Veronese (italiano, 1528-1588). Retrato del conde Giuseppe da Porto con su hijo, Adriano, ca. 1555. Óleo sobre lienzo; 247 x $133 \mathrm{~cm}$. Florencia: Galería de los Uffizi, inv. Contini Bonacossi no. 16.

"Lynx sp. at Spain during XIXth Century. A case of study from..." 
scarce at XVIIth century, frecuent for XVIIIth century and much more usual by the end of this century and the beginning of XIXth century.

Fouth stage is marked in dark blue. From 1850 to 1900 . It shows a huge decreased in Lynx population. It was the stage of development of Industrial Revolution in Spain. Railways were widely spread troug territory. Minnig of coal and Iron, siderurgy and farming change all territories in the north. Southern region around Huelva, Almeria y Murcia were huge mining centres. Villages becames towns in Asturias, Cantabria and Vasque Country. In the coast, towns becames cities. Population growth a lot near industrial areas. Inland territories lost habitants. Deforestation was increased as have never seen th country before. Public lands were sell by "desamortizaciones", so a huge number of dehesa and forest becames agricultural land.

Later periods for XXth century are well known, so we don't include it in our analizes.

\section{Conclusions}

Historical data about animal need a collaborative work between historians and biologist. Research from biologist can be unable to find data from historical documents. Biological research made by historian could have big mistakes about Ecology. In any case, biologist has done most of historical researches about fauna. Historians with a good knowledge of ecology are a needing. The data should be focuses from de Ecohistory, which works with a mixture of Geography, History, Archaeology and Ecology.

Method for historic studies of fauna can be taken from our paper. We made research using Laws, Journals, Administrative documents, local data from Actas plenarias, Prices, Trip books, ancient Environmental works, Dictionaries, Geographical research, biological resear, papernews, archaeological research, etc. 
We get more than 300 references for Lynx, near 110 references in bibliography and old paper news, 124 references from historic dictionaries, 24 references from archaeological remains from Holocene. Hence 254 are references for Lynx presence, Around 200 just for XIXth century.

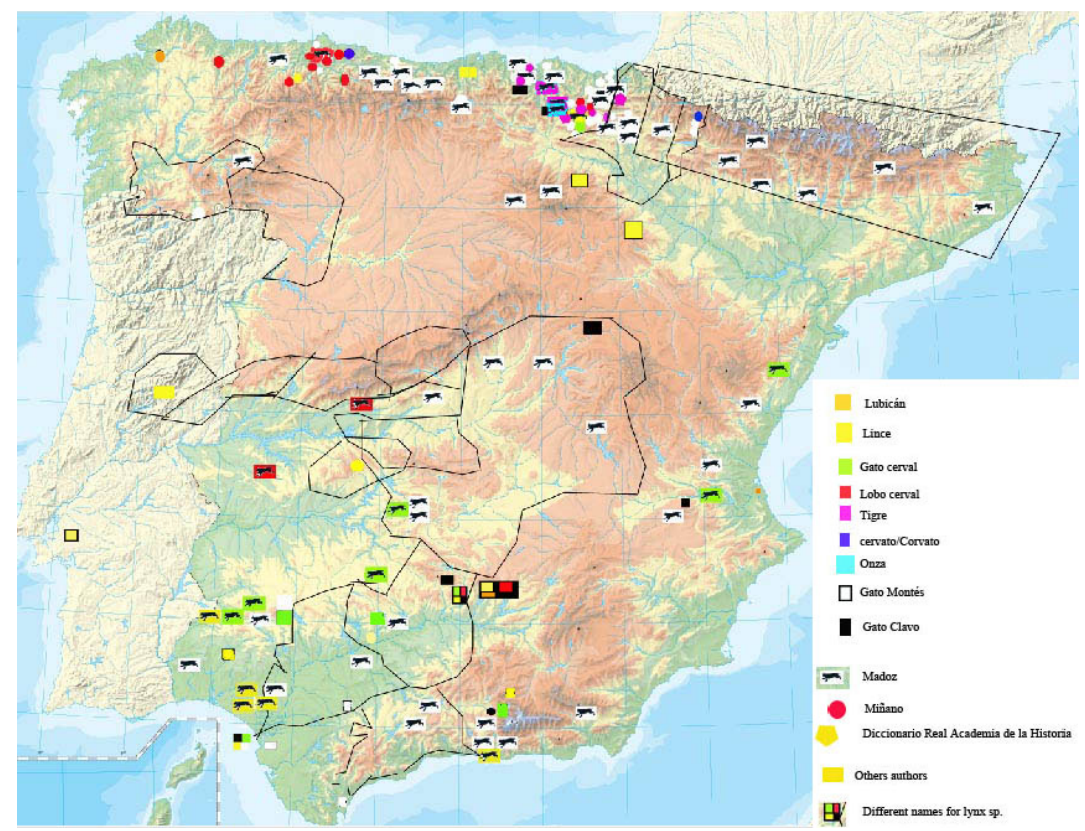

Figure 1. Lynx references by name and sources. Repeat locatios are omitted. Also Newspaper data, that is prepared for a future paper. Lines are around areas where documents say there are Lynxes, as Pirenees.

We find a concentration of data in Vasque Country, as Clavero and Delibes have done before. Also there are concentration at Cantabria, Asturias and a few places of Andalusia, as Doñana, Aracena mountains, Granada and Cordoba. Granada seems to be a refuge of Lynx quite bad known. It's unusual the scarce references at Tajus basin. We though that Toledo and Caceres should have the core of references but It doesn't happens. We understand that It is linked

"Lynx sp. at Spain during XIXth Century. A case of study from..." 
with no biological studies in these areas. Pyrenees habe a lot of references, but not too much references from XIXthcentury. We think that It's used Gato montes widely in this mountains. PrePyrenees seems to be a good place for Lynx sp.

About names, the wider number is in Vasque Country. It's a place where several names are used, but It is the place where "tigre" is most used. At Cantabria, absence of data shoul be taken as consecuence of no admission of Gato montes for Lynx. This word is widely used. Lince occurs in Cantabria at early XXth century at Valle de Buelna. Consequently, Lynxes of northen Spain were located from Galicia to Catalonia. Asturias has a general use of Lobo cerval and frequent use of Gato Montés. Dictionaries give us reference of Lubican just in Galicia. We show several references for this area, with lobo cerval and Gato Montés. Gato cerval and Gato Clavo are usual in Andalusia, but it occurs in Comunitat Valenciana and even in Vasque country. We should remember older references at this territory, from 1572 Bernedo, "gato cerbal", 1572 Santa Cruz de Campezo, "gato cerbal", 1597.

Lobo cerval occurs from north to south. Also it happens with Lince. So differences in naming are not relates with species, but with the writer. La Compañía Guipuzcuana de Caracas is the origin of La Compañía de Filipinas. Last one have "privilegios/ monopoly" of trade with Nueva España, today Mexico and United States. These two institutions for trade have deep root in the north, and It could be linked with the export of the name "Gato Montes" for "Lynx rufus" to america. It's a non native designation for lynx. It must be related with northen Spaniards. In addition, It could explain use of word "Tigre" for the spotted felidae, which is an Americanism brang by "indianos". Nores understood Tiguer is a word that came from America. We think he is right.

Every so often Lynx is quoted in different ways. Occasionally in administrative divitions: (Provinces of Sevilla, 
Guipúzcoa, Córdoba, Málaga, Zamora, Segovia, old kingdom of Navarre, etc.). Also it is refered in "partido judicial" (de Almadén, partido judicial de Motril) and others in a region or mountainous feature. (Sierra Morena, Encartaciones, Hoya de Baza, Pyrenees, Gredos). There are no data for long extensions as Duero basin and south of Aragón.

Newspaper data show Lynx sp as follows: Baza Mountains (Granada) (Lobo cerval, Lince, Gato clavo, 1840), Pirineos (Lince 1777, Lobo cerval, 1865), Castellbó- Seo de Urgel (Gato Montés, 1844), Torrelodones, (Seem Gato campesino, lobo cerval o Lince, 1865), Gredos (Pardo, Felis pardinus, gatopardo, lobo cerval, 1865), El Carbayón of Oviedo and concejos of Lena, Mieres; Quirós y Riosa, Morcín and Rivera de Arriba (Pantera, lobo cerval, 1884), Lobo Cerval, El Malillo, Los Pimpollares and la Hache (Lobo cerval, 1887) Orbaiceta. (Lobo cerval o lince, 1895) Cazalla- Constantina (Sevilla)(gato clavo, 1842) Malaga Province (Felis pardinus, Gato clavo, 1875) Sierra del Courel (Lugo), Villalba, San Pedro de Orazo (Pontevedra) (Lobo cerval, serval, tigre. $1861^{117}$ ), Torrejón El Rubio (Los Ibores) (Lobo cerbal, lince, 1886) Casas-Ibañez (Albacete) (Lince o lobo cerval, 1889) Early XX century (Hornachuelos), El Pedroso (Sevilla) (Gato cerval, 1910), Guadarrama (Lince, 1904, ¿Gato Montés? 1904)

We think that our work could be useful in conservative biology. Numerous of new location of Lynx have been quoted. Data about ecology have been collected. Some of the references came from northern Spain, where historical documents made no differences between Lynx Lynx and Lynx pardinus. Size and wheigth could be a help. Both species could be living in these territories, if we use archaeological data.

117 Its a resume of Seoane work at Diario de Pontevedra, so we always refer the original of Seoane.

"Lynx sp. at Spain during XIXth Century. A case of study from..." 
Maybe, we should take as true that there was a more aggressive behaviour of Lynx 200 years ago. Human have kill these aggressive animals, as could happen in Doñana. We have data that say that owners of Doñana kill most aggressive lynx. When Lynx kill young Fallow deer, there were hunts to kill that $\operatorname{lynx}{ }^{118}$.

Information that we have now for Lynx behaviour and ecology, can be different from It behaviour and ecology at XIXTh century. It also happens with environment linked with Lynx. 50 years ago, most of Lynxes at Spain were placed at Doñana, a lowland plain with pine trees forest, same Quercus suber and a huge wetland. Most of data we get tell us abou middle mountains with mixed forest. There are different ecosystem that make us to think about Lynxes in high mountains with coniferous forest near Quercus rotundifolia of northen areas (Ataun, Urdalaitz, Arno-Aranerreka, Urola, Anduts..). Most of quotes came from livestock areas. It usual Agropastoral system of Dehesa linked with Quercus suber or Quercus rotundifolia. The main difference between the historic study and actual data is that Lynx were living at places where rabbits were not abundant. At these northen areas there were hares and roe deer, and sometimes fallow deer. Many references about lynxes are connect with quotes of Wolf. Actually, we have no data about this ecosystem in Spain. Sometimes Linx is quoted alone. It can be related with reduced number of wolf and with value given to Felidae as a Big Game Trophy. It happens in Galicia, Sierra de San Pedro (Caceres), province of Segovia and Cordoba.

118 G. MONFORT, Retrato de una tierra..., 142. Picture of Don Mauricio Gonzaleswith a death lynx. We can read "algunos de estos animales deben de ser eliminados cuando matan demasiados gabatos". The idea is repeated in picture of a Young fallow deer at page 123. We can read "Por desgracia, los linces matan muchos en mayo y junio." 
About aggressive animals, Garrote, G. et alii 2013 made the first study about aggressive behaviour, non usual in Iberian lynx ${ }^{119}$. They said that conflict with farmers appear in Andujar- Cardeña, where Lynx increased because of conservation program. There were 31 attacks on birds (Chiken, Turkey, doves) and 9 attacks on lambs.

They refer the Linell theory of "problem animal", that explains that most of the attacks on livestock are related with isolated animal that develops unusual behaviour. A single individual radio tracked made six attacks. A total of "seven different Iberian lynx (four adult males, two subadult males, and one subadult female) were identified attacking coops. These individuals could be identified by means of radio tracking, photo trapping, or direct observation inside the coops".

Historical data show that there is indirect selection on animal behaviour made by humans. Where lynx attacks livestock animals, they were pursued until they were eliminated. In Doñana, when lynx attacked young fallow deer or red deer, the owner started hunting in the area for kill the "guilty" Lynx. Most aggressive animals were disappeared. Studies on Lynx behaviour were impossible to be taken out of natural reserve of Doñana where owners made a selective execution. Just rabbit eater animals were admitted.

At the moment, all the animals that have been taken from pictures and fur analysis of lynx in Spain and Portugal are related with Iberian Lynx, (Lynx pardinus). Eurasian Lynx (Lynx lynx) are not usually reported at the area, even if isolated individual could be seen in historical records at western Pyrenees. Anyhow, northern mountains are proved to have population of $\operatorname{Lyn} x \operatorname{ly} n x$

119 G Garrote, G. López, J.M., Gil, E. Rojas, M. Ruiz, J. Bueno segura, S. Lillo, J. Rodriguez-Siles, J. Martín, J. Pérez, M. Garcia-Tardio, G. Valenzuela, M. SIMON, Human-felid conflict as a further handicap to the conservation of the critically endangered Iberian lynx. European Journal of Wildlife Research 2013.

"Lynx sp. at Spain during XIXth Century. A case of study from..." 
and bynx pardinus at the same period. Doubtless, Pyrenees and Picos de Europa are excellent location for Lynx Lynx.

We understand that XIXth century data about lynx can be used in diversification of conservation strategies. Agressive animals can be placed in northen areas, where big sized preys are more frequent and lynx was widely distributed. Reintroduction centres for Iberian Lynx can work at Huesca, Lleida or Asturias. Another historical area is Galicia- Leon. Agressive individuals will be increased on hunting of Capreolus capreolus, Dama dama and Ovis egmelini. Even Rupicapra pirenaica and Capra pyrenaica can be taken as preys. It seems that it was usual at XIXth century, but not today. Most of Lynx pardinus have dependence of rabbit. No studies have been done yet. It is in biological work as DELIBES, M., Rodriguez, A., and FERreras, P. (2000) said that "Rabbits consistently account for $80-100 \%$ of the consumed biomass in the lynx diet.... Other vertebrates, including rodents, European hare (Lepus granatensis), red-legged partridge (Alectoris rufa), ducks, and geese (Anser anser) can be regularly killed and eaten in some areas and/or seasons, but they always contribute little to the lynx diet. Several ungulate species can occasionally be taken, especially in winter. Ungulate prey includes juvenile red (Cervus elaphus) and fallow deer (Dama dama), and mouflon (Ovis musimon). Roe deer (Capreolus capreolus) has not been reported as a prey, perhaps just because it is absent in the areas where the lynx diet has been studied" ${ }^{\prime 20}$.

Anyway, there is reference of ungulates predation. In Delibes de Castro, M. (1980) we can read 16 hunted preys, 11were cervidae. 8 of them are Dama dama, 3 of them Cervus elaphus. Weigh of preys is between 20, 22, $23 \mathrm{Kg}$. for Cervus, Fallow deer were selected in two clear size, Young ones between 17 and 25

\footnotetext{
120 M. Delibes, A. Rodriguez \& P. Ferreras, Action Plan for the Conservation of the iberian Lynx. (Lynx pardinus) in Europe. Bern Convention. Nature and Environment, 111. Council of Europe Publishing 2000, 18.
} 
$\mathrm{Kg}$, (5 in total) and adult animal, which weight were $36^{\prime} 75$, $38^{\prime} 25,45 \mathrm{~kg}$, (three in total) ${ }^{121}$.

Our proposal of historic distribution shows similarities with the 1960 data $^{122}$. Moreover, in northen Spain It is similar to the work of Peñin Agra, V. (2018). She found molecular data that show presence of Lynx Lynx and Lynx pardinus in northern Spain for Holocene. It is relevant the data for Pardel Lynx at Galicia in an area near the reference in $\mathrm{Madoz}^{123}$.

Lynxes can improve their chances of survival by diversifying their habitat, improving the connection between populations, and taking into account the elements of ecohistory that have been numbered in this study.

121 M. Delibes de CASTRo, El lince ibérico: ecología y comportamiento alimenticios en el Coto Doñana. Acta vertebrata ,7. Consejo Superior de Investigaciones Científicas. Estación Biológica de Doñana. Sevilla 1980. About deer as preis at pp. 124-126.

122http://www.iberlince.eu/index.php/esp/lince-ibericoesp/distribucion\#.XkwXdbiun58

${ }^{123}$ https://ruc.udc.es/dspace/bitstream/handle/2183/21171/Pe\%C3\%B1inAgra Virgi nia TFG 2018.pdf? sequence $=2$ \&isAllowed $=$ y See p. 20.

"Lynx sp. at Spain during XIXth Century. A case of study from..." 
RIPARIA VOL. 6 (2020)

Table 1. Felidae that can be taken as Lynx sp. Diccionario Geográfico 1802.

\begin{tabular}{lllll}
\hline $\begin{array}{l}\text { Diccionario } \\
\text { Geográfico- } \\
\mathbf{1 8 0 2}\end{array}$ & $\begin{array}{l}\text { Cita } \\
\text { destacada }\end{array}$ & $\begin{array}{l}\text { Referencia } \\
\text { geográfica }\end{array}$ & Provincia & $\begin{array}{l}\text { Referencia } \\
\text { Pág. }\end{array}$ \\
\hline $\begin{array}{l}\text { Gato } \\
\text { Montés }\end{array}$ & Leníz, & Guipuzcoa & Pág 432 \\
$\begin{array}{l}\text { Gato } \\
\text { Montés }\end{array}$ & & Aramayona & Álava, & Pág 85
\end{tabular}

\begin{tabular}{|c|c|c|c|c|}
\hline $\begin{array}{l}\text { Gato } \\
\text { Montés }\end{array}$ & $\begin{array}{l}\text { "Caza de ... } \\
\text { corzos, lobos } \\
\text { texorros , } \\
\text { texones } \\
\text { urones } \\
\text { silvestres , } \\
\text { gatos } \\
\text { monteses y } \\
\text { cerbales de } \\
\text { suma fiereza, } \\
\text { comadrejas" }\end{array}$ & Salvatierra & Álava. & Pág. 289. \\
\hline $\begin{array}{l}\text { Gato } \\
\text { Montés }\end{array}$ & $\begin{array}{l}\text { "animals } \\
\text { fieros, gatos } \\
\text { monteses y } \\
\text { lobos" }\end{array}$ & Ataún, & Guipuzcoa, & Pág 129, \\
\hline $\begin{array}{l}\text { Gato } \\
\text { Montés }\end{array}$ & & $\begin{array}{l}\text { Lazcano, en } \\
\text { Aretía, }\end{array}$ & Guipuzcoa. & Pág 425 \\
\hline $\begin{array}{l}\text { Gato } \\
\text { Montés }\end{array}$ & & Regil, En Sayaz & Guipuzcoa, & Pág. 269 \\
\hline $\begin{array}{l}\text { Gato } \\
\text { Montés }\end{array}$ & & Roncal, & Navarra. & Pág 277 \\
\hline $\begin{array}{l}\text { Gato } \\
\text { Montés }\end{array}$ & $\begin{array}{l}\text { "hallándose } \\
\text { en sus } \\
\text { montes lobos } \\
\text { gatos } \\
\text { monteses y } \\
\text { otras fieras" }\end{array}$ & $\begin{array}{l}\text { Trucios, en las } \\
\text { Encartaciones }\end{array}$ & Vizcaya. & Pág. 389 \\
\hline $\begin{array}{l}\text { Gato } \\
\text { Montés }\end{array}$ & $\begin{array}{l}\text { "hállanse en } \\
\text { los mismos } \\
\text { zorros } \\
\text { jabalíes y } \\
\text { gatos }\end{array}$ & Usurbil & Guipuzcoa. & Pág. 422. \\
\hline
\end{tabular}




\begin{tabular}{|c|c|c|c|c|}
\hline & monteses." & & & \\
\hline $\begin{array}{l}\text { Gato } \\
\text { Montés }\end{array}$ & $\begin{array}{l}\text { "jabalíes } \\
\text { zorros } \\
\text { garduños } \\
\text { gatos } \\
\text { monteses, } \\
\text { herizos } \\
\text { comadrejas y } \\
\text { muchas } \\
\text { liebres,..." }\end{array}$ & $\begin{array}{l}\text { Munguía, } \\
\text { prov.. }\end{array}$ & Vizcaya. & $\begin{array}{l}\text { Pág 44., no } \\
\text { puede } \\
\text { especificarse }\end{array}$ \\
\hline $\begin{array}{l}\text { Gato } \\
\text { cerbal* }\end{array}$ & $\begin{array}{l}\text { "Caza de ... } \\
\text { corzos, lobos } \\
\text { texorros , } \\
\text { texones } \\
\text { urones } \\
\text { silvestres } \\
\text { gatos } \\
\text { monteses y } \\
\text { cerbales de } \\
\text { suma fiereza, } \\
\text { comadrejas" }\end{array}$ & Salvatierra & Álava. & Pág. 289. \\
\hline Lobo cerval & $\begin{array}{l}\text { "Lobos } \\
\text { comunes y } \\
\text { cervales, } \\
\text { gatos } \\
\text { monteses y de } \\
\text { algalia,..." }\end{array}$ & $\begin{array}{l}\text { Geografía de } \\
\text { Navarra. } \\
\text { (About } \\
\text { Province }\end{array}$ & Navarra & Pág 63. \\
\hline Lobo cerval & $\begin{array}{l}\text { "Lobos } \\
\text { comunes y } \\
\text { cervales, } \\
\text { jabalíes, } \\
\text { corzos, } \\
\text { tasugos, } \\
\text { zorros, } \\
\text { garduñas, } \\
\text { gatos } \\
\text { monteses, } \\
\text { liebres } \\
\text { comadrejas }\end{array}$ & Oñate. & Guipuzcoa & Pág 195. \\
\hline Tigre & $\begin{array}{l}\text { Caza de } \\
\text { muchos }\end{array}$ & Cegama & Guipuzcoa. & Pág 206. \\
\hline
\end{tabular}


RIPARIA VOL. 6 (2020)

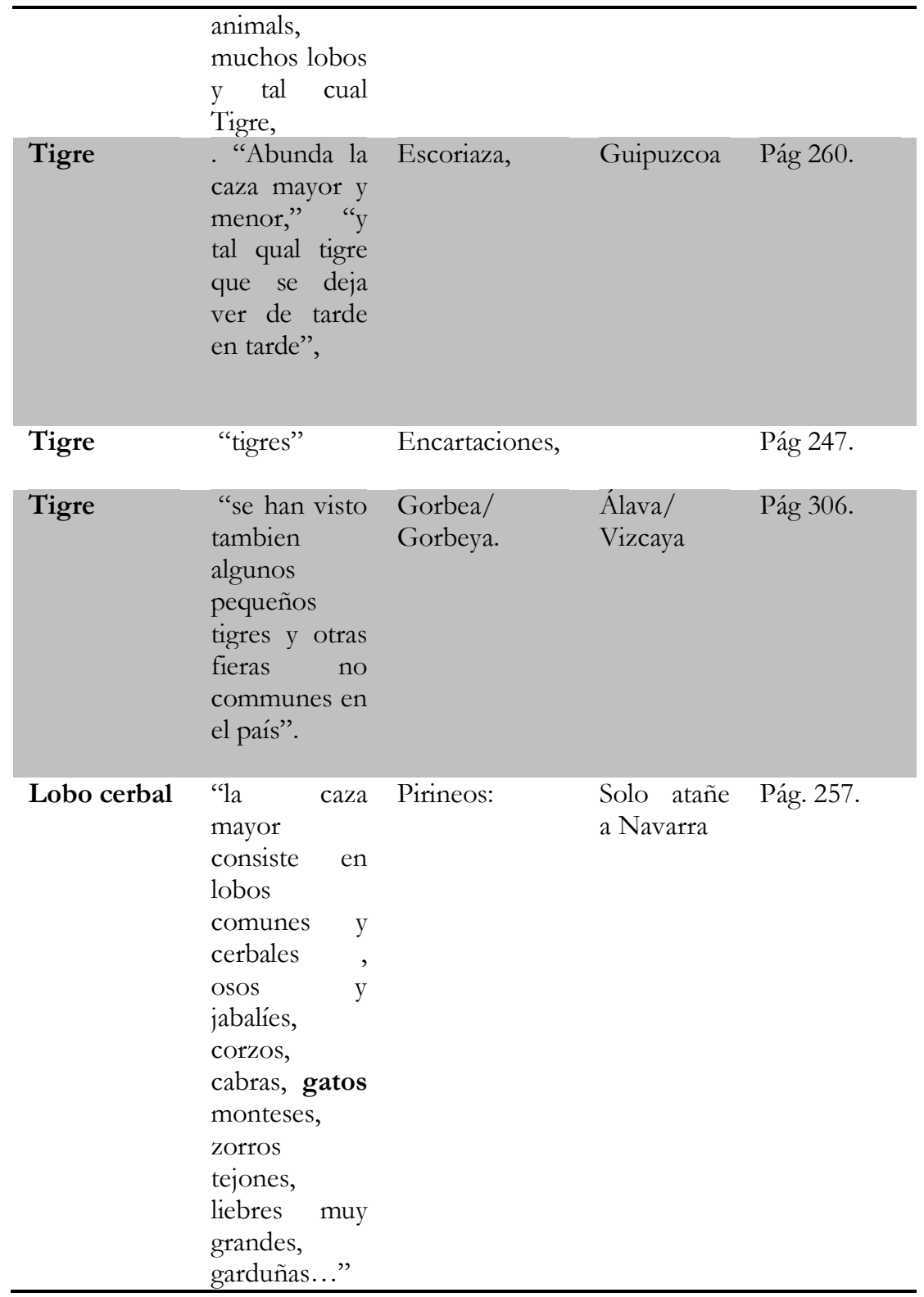




\section{A. ViLLALPANDO MORENO}

Table 2: Diccionario Geográfico y Estadístico de España y Portugal", By Miñano y Bedoya, S. From 1826

\begin{tabular}{|c|c|c|c|c|}
\hline Municipio & Provincia & Lema & $\begin{array}{l}\text { Otros datos } \\
\text { biologicos }\end{array}$ & \\
\hline Aldaba & Guipúzcoa & $\begin{array}{l}\text { Gatos } \\
\text { montese } \\
\text { s }\end{array}$ & $\begin{array}{lr}\text { Se } & \text { crían } \\
\text { jabalíes, } & \\
\text { zorros, } & \\
\text { corzos } & \text { y } \\
\text { gatos } & \\
\text { monteses. } & \end{array}$ & \\
\hline Ataún & Guipuzcoa & $\begin{array}{l}\text { Gatos } \\
\text { montese } \\
\text { s }\end{array}$ & $\begin{array}{l}\text { Gran } \\
\text { multitud de } \\
\text { aves y } \\
\text { animales } \\
\text { fieros, gatos } \\
\text { monteses, } \\
\text { lobos, corzos, } \\
\text { jabalíes, } \\
\text { liebres, } \\
\text { raposos, } \\
\text { garduñas, } \\
\text { mucharros y } \\
\text { otras. }\end{array}$ & \\
\hline Avilés & Asturias & $\begin{array}{l}\text { Gatos } \\
\text { montese } \\
\mathrm{s}\end{array}$ & $\begin{array}{l}\text { Liebres, } \\
\text { algunos } \\
\text { jabalíes y } \\
\text { corzos, de los } \\
\text { dañinos, } \\
\text { lobos, zorros, } \\
\text { melandros o } \\
\text { tejones, } \\
\text { hurones, } \\
\text { comadrejas, } \\
\text { gatos } \\
\text { monteses, } \\
\text { martas, } \\
\text { fuinas, erizos } \\
\text { y nutrias. }\end{array}$ & \\
\hline $\begin{array}{l}\text { Beba (San } \\
\text { Julian de ) } \\
\text { Muros }\end{array}$ & $\begin{array}{ll}\text { Provincia } & \text { de } \\
\text { Santiago } & \text { (A } \\
\text { Coruña) } & \end{array}$ & $\begin{array}{l}\text { Gatos } \\
\text { montese } \\
\mathrm{s}\end{array}$ & $\begin{array}{l}\text { Algunos } \\
\text { animales } \\
\text { bravos, como } \\
\text { gatos }\end{array}$ & Monte Pindo \\
\hline
\end{tabular}

"Lynx sp. at Spain during XIXth Century. A case of study from..." 
RIPARIA VOL. 6 (2020)

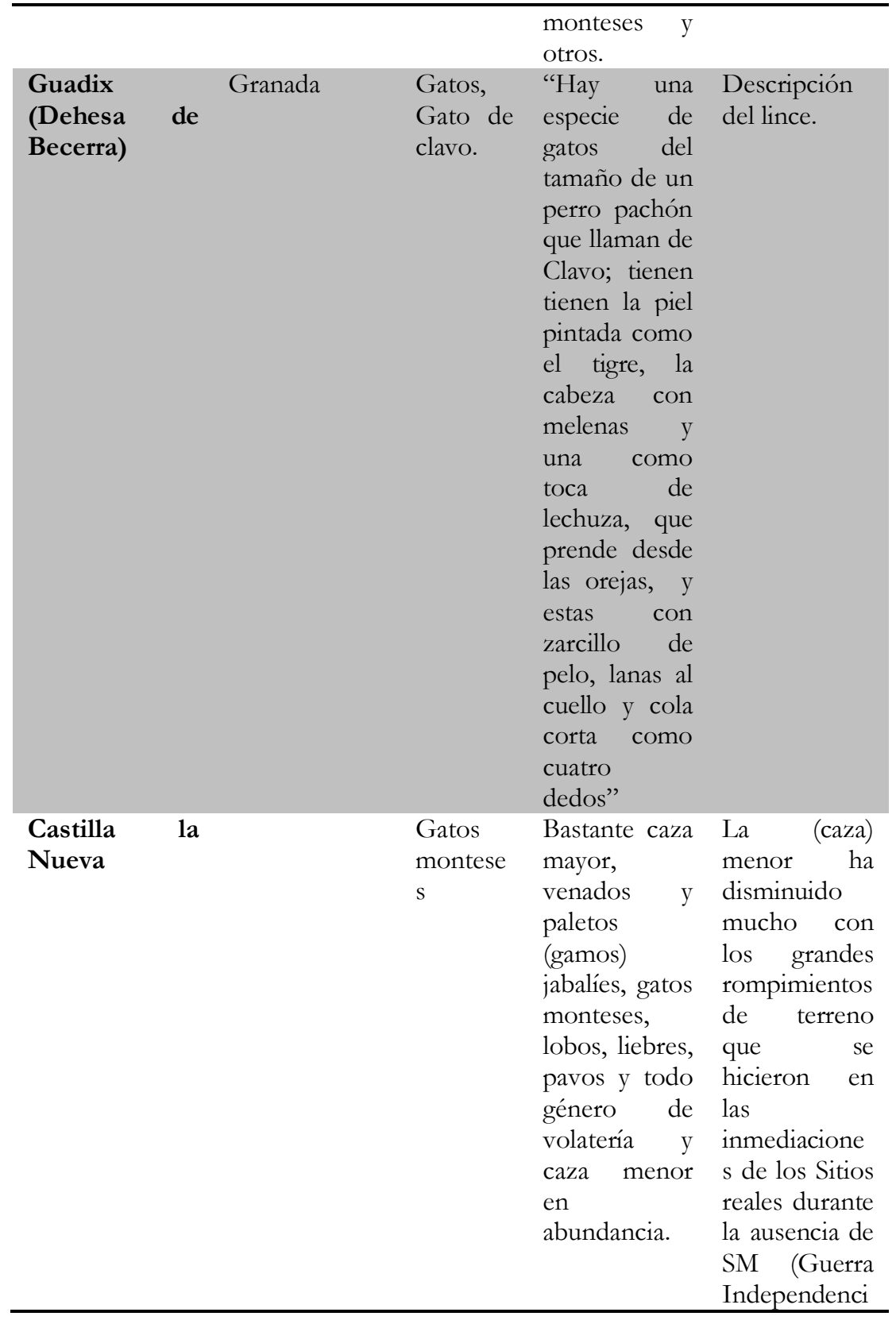




\begin{tabular}{|c|c|c|c|c|}
\hline & & & & $\begin{array}{ll}\text { a) a los } \\
\text { principios } & \text { de } \\
\text { su reinado. }\end{array}$ \\
\hline Cabrales & Asturias & $\begin{array}{l}\text { Cervatos } \\
\text { gatos } \\
\text { montese } \\
\text { s. }\end{array}$ & $\begin{array}{l}\text { Muchas } \\
\text { bestias fieras, } \\
\text { osos, lobos, } \\
\text { cervatos, } \\
\text { zorras, varias } \\
\text { especies de } \\
\text { gatos } \\
\text { monteses } \\
\text { muy } \\
\text { perjudiciales } \\
\text { a los ganados } \\
\text { mayores } \\
\text { menores. En } \\
\text { las peñas más } \\
\text { altas } \\
\text { rebezos... en } \\
\text { los valles de } \\
\text { hallan corzos } \\
\text { y una especie } \\
\text { de cabra } \\
\text { montés } \\
\text { parecida a las } \\
\text { comunes.. } \\
\text { que llaman en } \\
\text { el país } \\
\text { mueyos. }\end{array}$ & \\
\hline $\begin{array}{l}\text { Concejo de } \\
\text { Caso. } \\
\text { Campo, Orle, } \\
\text { Tarna, } \\
\text { Sobrecastiello, } \\
\text { Pendones, } \\
\text { Braeres, } \\
\text { Tanes, } \\
\text { Coballes, } \\
\text { Caleado } \\
\text { Tozo. }\end{array}$ & Asturias & $\begin{array}{l}\text { Lobo } \\
\text { cerval }\end{array}$ & $\begin{array}{l}\text { Abunda en } \\
\text { osos, jabalíes, } \\
\text { lobos } \\
\text { comunes y } \\
\text { algún otro } \\
\text { cerval, en } \\
\text { corzos, } \\
\text { robezos, } \\
\text { tejones, } \\
\text { zorros y } \\
\text { alguna liebre. }\end{array}$ & \\
\hline Cerain & Guipuzcua & $\begin{array}{l}\text { Gato } \\
\text { Montés }\end{array}$ & $\begin{array}{l}\text { En todos sus } \\
\text { montes se }\end{array}$ & $\begin{array}{l}\text { Tomo III, } \\
\text { pág. } 57 .\end{array}$ \\
\hline
\end{tabular}

"Lynx sp. at Spain during XIXth Century. A case of study from..." 
RIPARIA VOL. 6 (2020)

\begin{tabular}{|c|c|c|c|c|}
\hline & & & $\begin{array}{l}\text { crían liebres, } \\
\text { raposos, } \\
\text { gatos } \\
\text { monteses y } \\
\text { hay pasto... }\end{array}$ & \\
\hline $\begin{array}{l}\text { Collera (San } \\
\text { Martín de) }\end{array}$ & Asturias & $\begin{array}{l}\text { Gato } \\
\text { montés }\end{array}$ & $\begin{array}{l}\text { Lobos, } \\
\text { jabalíes, } \\
\text { zorros, algún } \\
\text { corzo, liebres, } \\
\text { gatos } \\
\text { monteses, y } \\
\text { melandros } \\
\text { que } \\
\text { Castilla en } \\
\text { llaman } \\
\text { Tejones }\end{array}$ & $\begin{array}{l}\text { Tomo III, } \\
\text { pág. } 150\end{array}$ \\
\hline Cegama & Guipuzcoa & tigre & $\begin{array}{l}\text { Perdices y } \\
\text { liebres en } \\
\text { abundancia, } \\
\text { tordos, } \\
\text { malvises, y } \\
\text { arrendajos, } \\
\text { corzos, } \\
\text { jabalíes lobos } \\
\text { y tal cual tigre }\end{array}$ & $\begin{array}{l}\text { Tomo III, } \\
\text { pág } 44 .\end{array}$ \\
\hline Encartaciones & Vizcaya & Tigre & $\begin{array}{l}\text { Algunos } \\
\text { jabalíes, } \\
\text { tigres, zorros } \\
\text { y otros } \\
\text { animales } \\
\text { nocivos }\end{array}$ & $\begin{array}{l}\text { Tomo III, } \\
\text { pág } 345 .\end{array}$ \\
\hline $\begin{array}{l}\text { Santa María } \\
\text { de Gestoso y } \\
\text { Valle de } \\
\text { Doresja. }\end{array}$ & $\begin{array}{l}\text { Coruña(Antig } \\
\text { ua provincia } \\
\text { de Betanzos }\end{array}$ & Lubican & $\begin{array}{l}\text { Lobos... } \\
\text { otros } \\
\text { animales de } \\
\text { menos } \\
\text { cuerpo } \\
\text { igualmente } \\
\text { feroces, } \\
\text { llamados } \\
\text { lubicanes }\end{array}$ & $\begin{array}{l}\text { El lanar y } \\
\text { cabrío por } \\
\text { otros } \\
\text { animales de } \\
\text { menos } \\
\text { cuerpo e } \\
\text { igualmente } \\
\text { feroces, } \\
\text { llamados } \\
\text { lubicanes, que } \\
\text { trepan por los }\end{array}$ \\
\hline
\end{tabular}




\begin{tabular}{|c|c|c|c|c|}
\hline & & & & 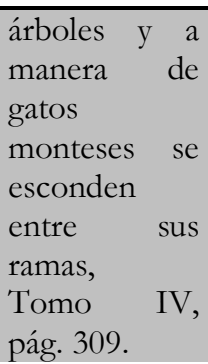 \\
\hline Gorbea & $\begin{array}{l}\text { Entre Álava y } \\
\text { Vizcaya }\end{array}$ & Tigres & $\begin{array}{l}\text { Algunos } \\
\text { pequeños } \\
\text { tigres no } \\
\text { comunes en } \\
\text { el país }\end{array}$ & $\begin{array}{ll}\text { Tomo } & \text { IV } \\
\text { pág. 331. } & \end{array}$ \\
\hline $\begin{array}{l}\text { Guadalupe } \\
\text { (Sierras de) }\end{array}$ & Caceres & lince & $\begin{array}{lr}\text { Bosques de } & \text { de } \\
\text { castaños que } & \text { dirven a los } \\
\text { asilo a } & \text { dervos, a los } \\
\text { cierzos, a los } \\
\text { jabalíes y a } \\
\text { los linces. }\end{array}$ & $\begin{array}{l}\text { Tomo } \\
\text { pág } 385 .\end{array}$ \\
\hline Iranzu & Guipuzcoa & $\begin{array}{l}\text { Gato } \\
\text { montes }\end{array}$ & $\begin{array}{l}\text { Raposos, } \\
\text { gatos y cabras } \\
\text { monteses, } \\
\text { garduñas y } \\
\text { jabalíes }\end{array}$ & $\begin{array}{l}\text { Tomo V, pág. } \\
63 .\end{array}$ \\
\hline $\begin{array}{l}\text { Langreo } \\
\text { Concejo de. } \\
\text { (Sama, Bliea, } \\
\text { San Martín } \\
\text { del Rey } \\
\text { Aurelio, San } \\
\text { Andrés, } \\
\text { Ciaño, } \\
\text { Turiellos, } \\
\text { Barros, Barros } \\
\text { Lada y } \\
\text { Riaño) }\end{array}$ & Asturias & $\begin{array}{l}\text { Cervales, } \\
\text { lobo } \\
\text { cerval. }\end{array}$ & $\begin{array}{l}\text { Su caza } \\
\text { perdices, } \\
\text { arceas, } \\
\text { palomos, } \\
\text { torcaces, } \\
\text { codornices, } \\
\text { jabalíes, } \\
\text { corzos, lobos, } \\
\text { zorros y } \\
\text { lobos que } \\
\text { llaman } \\
\text { cervales. }\end{array}$ & \\
\hline Morcín & Asturias & $\begin{array}{l}\text { Gato } \\
\text { montés, } \\
\text { lobo }\end{array}$ & $\begin{array}{l}\text { De animales } \\
\text { montaraces } \\
\text { hay taposas, }\end{array}$ & $\begin{array}{l}\text { Tomo } \\
\text { pág. } 143 .\end{array}$ \\
\hline
\end{tabular}

"Lynx sp. at Spain during XIXth Century. A case of study from..." 
RIPARIA VOL. 6 (2020)

\begin{tabular}{|c|c|c|c|c|}
\hline & & cerval & $\begin{array}{l}\text { tejones y } \\
\text { garduñas, } \\
\text { algunos gatos } \\
\text { monteses, } \\
\text { lobos } \\
\text { comunes y } \\
\text { cervales, } \\
\text { cuyas pieles, } \\
\text { por sus } \\
\text { manchas, se } \\
\text { parecen } \\
\text { mucho a la } \\
\text { del tigre, }\end{array}$ & \\
\hline Munguía & Vizcaya & $\begin{array}{l}\text { Gatos } \\
\text { montese } \\
\text { s }\end{array}$ & $\begin{array}{l}\text { Algunos } \\
\text { jabalíes, } \\
\text { zorros, } \\
\text { garduños, } \\
\text { gatos } \\
\text { monteses, } \\
\text { erizos, } \\
\text { comadrejas, y } \\
\text { muchas } \\
\text { liebres. }\end{array}$ & $\begin{array}{ll}\text { Posible felis } \\
\text { silvestris } \\
\text { Tomo } \\
\text { pág. 181. }\end{array}$ \\
\hline Oñate & Guipuzcoa & $\begin{array}{l}\text { Gatos } \\
\text { montese } \\
\text { s } \\
\text { Lobo } \\
\text { cerval }\end{array}$ & $\begin{array}{l}\text { Entre los } \\
\text { cuadrúpedos, } \\
\text { lobos } \\
\text { comunes y } \\
\text { cervales, } \\
\text { jabalíes, } \\
\text { corzos, } \\
\text { tasugos, } \\
\text { zorros, } \\
\text { garduñas, } \\
\text { gatos } \\
\text { monteses, } \\
\text { liebres } \\
\text { comadrejas }\end{array}$ & $\begin{array}{l}\text { Posible Felis } \\
\text { silvestris, } \\
\text { Tomo VI, } \\
\text { pág. } 527\end{array}$ \\
\hline $\begin{array}{l}\text { Monte Pindo } \\
\text { (Muros) }\end{array}$ & $\begin{array}{l}\text { La Coruña } \\
\text { (Santiago) }\end{array}$ & $\begin{array}{l}\text { Gatos } \\
\text { montese } \\
\text { s }\end{array}$ & $\begin{array}{l}\text { Se mantienen } \\
\text { los gatos } \\
\text { monteses y } \\
\text { otros } \\
\text { animales }\end{array}$ & $\begin{array}{l}\text { Tomo VII, } \\
\text { Pág. } 21 .\end{array}$ \\
\hline
\end{tabular}




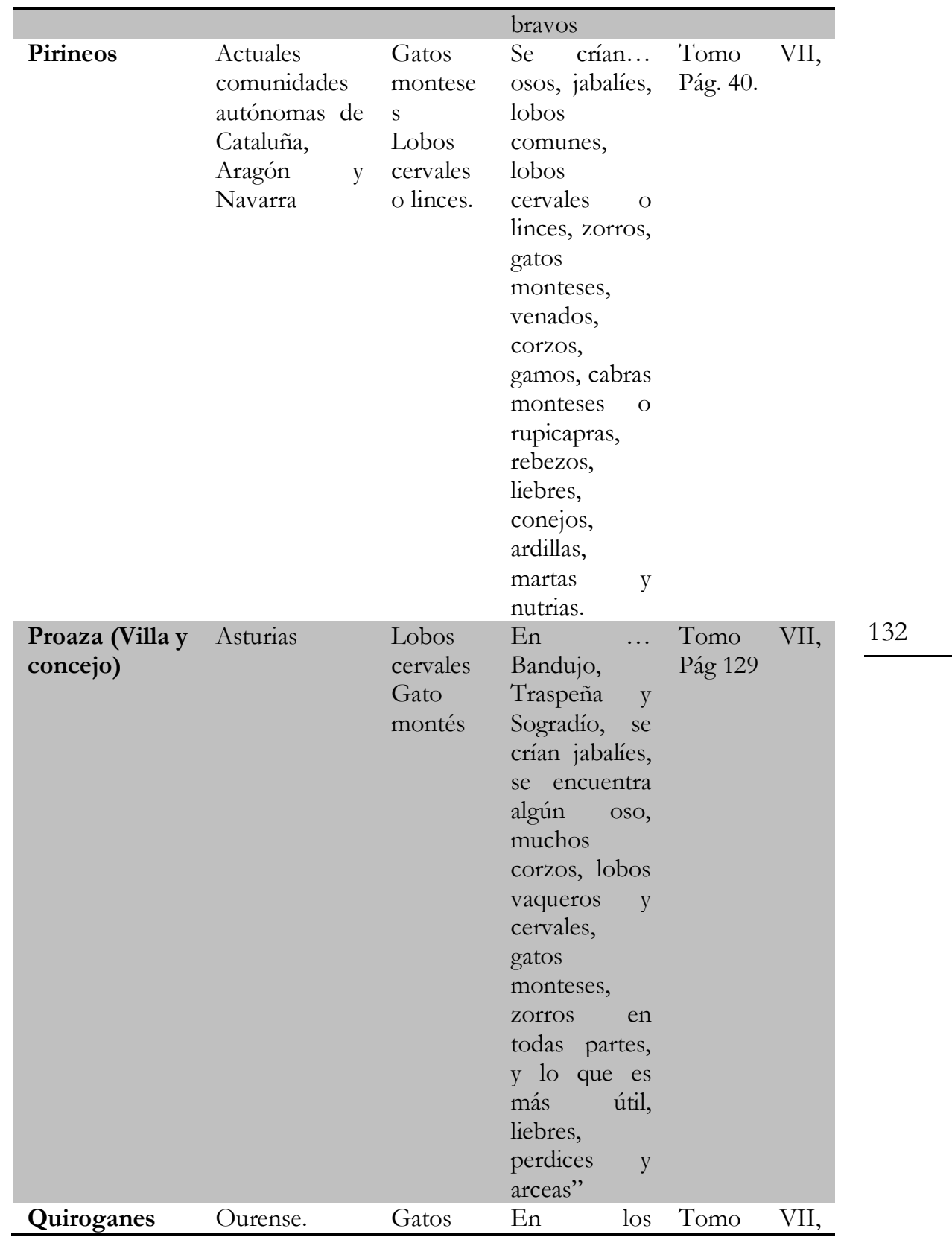

"Lynx sp. at Spain during XIXth Century. A case of study from..." 
RIPARIA VOL. 6 (2020)

\begin{tabular}{|c|c|c|c|c|c|}
\hline $\begin{array}{l}\text { (San Salvador } \\
\text { de ) }\end{array}$ & $\begin{array}{l}\text { Valle de } \\
\text { Monterrey) }\end{array}$ & $\begin{array}{l}\text { montese } \\
\mathrm{s}\end{array}$ & $\begin{array}{l}\text { montes... } \\
\text { jabalíes, } \\
\text { venados, } \\
\text { lobos, gatos } \\
\text { monteses, } \\
\text { gamos, } \\
\text { zorras, } \\
\text { conejos y } \\
\text { liebres" }\end{array}$ & Pág 219 & \\
\hline Regil (Sayas & Guipuzcoa & $\begin{array}{l}\text { Gatos } \\
\text { montese } \\
\text { s }\end{array}$ & $\begin{array}{l}\text { Algunos } \\
\text { jabalíes, } \\
\text { raposos, } \\
\text { gatos } \\
\text { monteses, } \\
\text { liebres, y las } \\
\text { aves } \\
\text { comunes" }\end{array}$ & $\begin{array}{l}\text { Tomo } \\
\text { Pág. } 250\end{array}$ & VII, \\
\hline Reinosa & $\begin{array}{l}\text { Palencia } \\
\text { (Hoy } \\
\text { Cantabria) }\end{array}$ & $\begin{array}{l}\text { Gatos } \\
\text { montese } \\
\mathrm{s}\end{array}$ & $\begin{array}{l}\text { "En Montes } \\
\text { Claros... y } \\
\text { Valdearroyo } \\
\ldots \text { se crían } \\
\text { lobos, osos, } \\
\text { corzos, } \\
\text { jabalíes, } \\
\text { tasugos, } \\
\text { rebesos, gatos } \\
\text { monteses y } \\
\text { todo género } \\
\text { de caza, } \\
\text { menos los } \\
\text { conejos, que } \\
\text { no se } \\
\text { conocen en } \\
\text { aquel país" }\end{array}$ & $\begin{array}{l}\text { Tomo } \\
\text { Pág. } 258 .\end{array}$ & VII, \\
\hline $\begin{array}{l}\text { Roncal (Valle } \\
\text { del) } \\
\text { Roncal, Isaba, } \\
\text { Ustarroz, } \\
\text { Urzainqui, } \\
\text { Garde, } \\
\text { Vidangoz, } \\
\text { Burgui, }\end{array}$ & Navarra & $\begin{array}{l}\text { Cervatos } \\
\text { Gatos } \\
\text { montese } \\
\text { s }\end{array}$ & $\begin{array}{l}\text { Se crían en } \\
\text { ellos lobos, } \\
\text { cervatos, } \\
\text { corzos, osos, } \\
\text { jabalíes, } \\
\text { cabras y gatos } \\
\text { monteses, } \\
\text { zorros, }\end{array}$ & $\begin{array}{l}\text { Tomo } \\
\text { Pág. } 359\end{array}$ & VII, \\
\hline
\end{tabular}




\begin{tabular}{|c|c|c|c|c|}
\hline & & & $\begin{array}{l}\text { tejones, } \\
\text { ardillas } \\
\text { garduñas } \quad \text { y } \\
\text { liebres " }\end{array}$ & \\
\hline Posadas & Córdoba & Lince & $\begin{array}{lr}\text { Mucha } & \text { caza } \\
\text { mayor, } & \text { y } \\
\text { entre } & \text { ella } \\
\text { algunos } & \\
\text { linces. } & \end{array}$ & \\
\hline $\begin{array}{l}\text { Santo Adriano } \\
\text { (Concejo) } \\
\text { Villanueva }\end{array}$ & Asturias & $\begin{array}{l}\text { Lobos } \\
\text { cervales } \\
\text { Gatos } \\
\text { montese } \\
\text { s }\end{array}$ & $\begin{array}{l}\text { "animales } \\
\text { bravos y } \\
\text { dañinos; } \\
\text { zorros, lobos } \\
\text { vaqueros y } \\
\text { cervales, } \\
\text { gatos } \\
\text { monteses... } \\
\text { de vez en } \\
\text { cuando } \\
\text { algunos osos } \\
\text { y rebezos" }\end{array}$ & $\begin{array}{l}\text { Tomo VIII, } \\
\text { Pág } 147\end{array}$ \\
\hline $\begin{array}{l}\text { Segovia } \\
\text { (Provincia) }\end{array}$ & Segovia & $\begin{array}{l}\text { Gatos } \\
\text { montese } \\
\text { s }\end{array}$ & $\begin{array}{l}\text { Ganado lanar } \\
\text { estante,jabalíe } \\
\text { s, paletos, } \\
\text { ciervos, gatos } \\
\text { monteses, } \\
\text { zorras, } \\
\text { liebres, } \\
\text { conejos y } \\
\text { volatería. }\end{array}$ & $\begin{array}{l}\text { Tomo VIII, } \\
\text { Pág. } 186\end{array}$ \\
\hline $\begin{array}{l}\text { Sevilla } \\
\text { (Provincia) }\end{array}$ & Sevilla & $\begin{array}{l}\text { Gatos } \\
\text { cervales } \\
\text { o } \\
\text { montese } \\
\text { s. }\end{array}$ & $\begin{array}{l}\text { "Los } \\
\text { animales } \\
\text { dañinos que } \\
\text { más } \\
\text { comúnmente } \\
\text { se encuentran } \\
\text { en esta } \\
\text { provincia, } \\
\text { son lobos, } \\
\text { raposas, gatos } \\
\text { cervales o } \\
\text { monteses, }\end{array}$ & $\begin{array}{l}\text { Tomo VIII, } \\
\text { Pág. } 235 .\end{array}$ \\
\hline
\end{tabular}

"Lynx sp. at Spain during XIXth Century. A case of study from..." 
RIPARIA VOL. 6 (2020)

\begin{tabular}{|c|c|c|c|c|}
\hline & & & $\begin{array}{l}\text { comadrejas, } \\
\text { tejones, } \\
\text { turones, } \\
\text { patialbillos... }\end{array}$ & \\
\hline $\begin{array}{l}\text { Toledo } \\
\text { (Provincia) }\end{array}$ & Toledo & $\begin{array}{l}\text { Gatos } \\
\text { montese } \\
\text { s }\end{array}$ & $\begin{array}{l}\text { "jabalíes, } \\
\text { venados, } \\
\text { lobos, gatos } \\
\text { monteses, } \\
\text { gamos zorras, } \\
\text { conejos y } \\
\text { liebres" }\end{array}$ & $\begin{array}{l}\text { Tomo VIII, } \\
\text { Pág, } 444 .\end{array}$ \\
\hline $\begin{array}{lr}\text { Torea } & \text { (San } \\
\text { Julian } & \text { de) } \\
\text { Muros } & \end{array}$ & $\begin{array}{l}\text { Santiago } \quad(\mathrm{La} \\
\text { Coruña) }\end{array}$ & $\begin{array}{l}\text { Gatos } \\
\text { montese } \\
\mathrm{s}\end{array}$ & $\begin{array}{l}\text { "algunos } \\
\text { animales } \\
\text { bravos como } \\
\text { gatos } \\
\text { monteses" }\end{array}$ & $\begin{array}{l}\text { Tomo VIII, } \\
\text { Pág. } 473 .\end{array}$ \\
\hline $\begin{array}{l}\text { Montes de } \\
\text { Gredos, y las } \\
\text { que continúan } \\
\text { y unen a estas } \\
\text { con los } \\
\text { montes lusitánicos } \\
\text { En lema: Tajo }\end{array}$ & $\begin{array}{l}\text { Avila, } \\
\text { Salamanca, } \\
\text { Toledo y } \\
\text { Caceres }\end{array}$ & Linces & $\begin{array}{l}\text { "piaras de } \\
\text { ganado } \\
\text { merino...que } \\
\text { conducen } \\
\text { pastores... } \\
\text { que los } \\
\text { defienden no } \\
\text { solo de los } \\
\text { lobos, sino de } \\
\text { los linces, } \\
\text { zorras y otros } \\
\text { animales } \\
\text { dañinos que } \\
\text { abundan en } \\
\text { las montañas } \\
\text { de..." }\end{array}$ & $\begin{array}{l}\text { Tomo VIII, } \\
\text { Pág. } 370\end{array}$ \\
\hline $\begin{array}{lr}\text { Santa } & \text { Eulalia } \\
\text { de } & \text { Oscos } \\
\text { (Concejo) }\end{array}$ & Asturias & $\begin{array}{l}\text { Lobos } \\
\text { cervales }\end{array}$ & $\begin{array}{l}\text { Hay gran } \\
\text { número de } \\
\text { lobos } \\
\text { cervales, muy } \\
\text { parecidos al } \\
\text { tigre, corzos y } \\
\text { gatos } \\
\text { silvestres }\end{array}$ & $\begin{array}{l}\text { Tomo VIII, } \\
\text { Pág. } 94\end{array}$ \\
\hline Somiedo & Asturias & Lobos & "Se crían en & Tomo \\
\hline
\end{tabular}




\section{A. VILLALPANDO MORENO}

\begin{tabular}{|c|c|c|c|c|}
\hline \multicolumn{2}{|l|}{ (Concejo) } & $\begin{array}{l}\text { cervales } \\
\text { Lince }\end{array}$ & $\begin{array}{l}\text { sus montes } \\
\text { osos, lobos, } \\
\text { jabalíes, } \\
\text { tejones, } \\
\text { robezos, y } \\
\text { ardillas } \\
\text { algún venado } \\
\text { y liebres, y } \\
\text { lobos } \\
\text { cervales, que } \\
\text { parecen ser } \\
\text { los que } \\
\text { Buffon llama } \\
\text { linces" }\end{array}$ & Pág. 322. \\
\hline $\begin{array}{l}\text { Trucios } \\
\text { (Encartacione } \\
\text { s) }\end{array}$ & Vizcaya & $\begin{array}{l}\text { Gatos } \\
\text { montese } \\
\text { s }\end{array}$ & $\begin{array}{l}\text { "hallándose } \\
\text { en sus } \\
\text { montes } \\
\text { lobos, gatos } \\
\text { monteses y } \\
\text { otras fieras" }\end{array}$ & $\begin{array}{l}\text { Tomo IX, } \\
\text { pág. } 83\end{array}$ \\
\hline $\begin{array}{l}\text { Zamora } \\
\text { (Provincia) }\end{array}$ & Zamora & $\begin{array}{l}\text { Gatos } \\
\text { montese } \\
\text { s }\end{array}$ & $\begin{array}{l}\text { "críanse } \\
\text { jabalíes, } \\
\text { lobos, zorras, } \\
\text { gatos } \\
\text { monteses, } \\
\text { corzos, } \\
\text { venados, } \\
\text { liebres, } \\
\text { conejos y de } \\
\text { todo género } \\
\text { de caza en } \\
\text { abundancia" }\end{array}$ & $\begin{array}{l}\text { Tomo X, pág. } \\
67 .\end{array}$ \\
\hline
\end{tabular}


Table 3. References of Lynx sp. from Madoz Dictionary. 1845.

\begin{tabular}{|c|c|c|}
\hline Region/ Province & Place (Not translated) & $\begin{array}{l}\text { References } \\
\text { (not translated) }\end{array}$ \\
\hline Andalusia/ Almería & Bacares & Gatos Monteses \\
\hline Andalusia/ Córdoba & Córdoba (Ciudad) & Gatos monteses \\
\hline Andalusia/ Granada & Albuñuelas & Gatos monteses \\
\hline Andalusia/ Granada & $\begin{array}{l}\text { Casulas, } \\
\text { Granada }\end{array}$ & Gatos monteses \\
\hline Andalusia/ Granada & Loja & Gatos monteses \\
\hline Andalusia/, Granada & Motril (Partido Judicial) & $\begin{array}{l}\text { Lince } \\
\text { Gatos monteses ¿? }\end{array}$ \\
\hline Andalusia/ Granada & Los Tablones, Motril & Gatos Monteses \\
\hline Andalusia/ Huelva & $\begin{array}{l}\text { Cumbres de San } \\
\text { Bartolomé }\end{array}$ & Gatos cervales \\
\hline Andalusia/ Huelva & Aroche & $\begin{array}{l}\text { gatos cervales } \\
\text { linces }\end{array}$ \\
\hline Andalusia/ Huelva & Bollullos del Condado & linces \\
\hline Andalusia/ Huelva & Almendro, Ayamonte & $\begin{array}{l}\text { Animales de la especie } \\
\text { de gatos monteses }\end{array}$ \\
\hline Andalusia/ Huelva & Hinojos & Linces* \\
\hline Andalusia/ Huelva & Almonte & Linces* \\
\hline Andalusia/ Huelva & Castaño del Robledo. & gato \\
\hline Andalusia/ Málaga & Malaga provincia & $\begin{array}{l}\text { Gatos monteses con } \\
\text { pieles atigradas }\end{array}$ \\
\hline Andalusia/ Málaga & Alfarnate & Gatos Monteses \\
\hline Andalusia/ Sevilla & Sevilla Provincia & Gatos monteses \\
\hline Andalusia/ Sevilla & Sanlúcar La Mayor & Gatos monteses \\
\hline Andalusia/ Sevilla & Écija & Gatos monteses \\
\hline Aragón/ Huesca & Anzanigo & Gatos monteses \\
\hline Aragón/ Huesca & Bacamorta & Gatos Monteses \\
\hline Aragón/ Huesca & Castisaba & Gatos Monteses \\
\hline Aragón/ Huesca & Benabarre & Gatos monteses \\
\hline Asturias & Morcin & $\begin{array}{l}\text { "Lobos cervales cuyas } \\
\text { pieles manchadas se } \\
\text { parecen a del tigre" } \\
\text { "Gatos monteses" }\end{array}$ \\
\hline Asturias & Cabrales & $\begin{array}{l}\text { varias especies de gatos } \\
\text { monteses muy } \\
\text { perjudiciales } \\
\text { á los ganados }\end{array}$ \\
\hline Asturias & Cangas de Onís & gatos monteses \\
\hline Asturias & Cangas de Tineo & Gatos monteses \\
\hline
\end{tabular}




\begin{tabular}{|c|c|c|}
\hline Asturias/ Oviedo & San Cristobal de Tielbe & Gatos Monteses \\
\hline $\begin{array}{l}\text { Basque Country/ } \\
\text { Alava }\end{array}$ & $\begin{array}{ll}\text { Sopuerta, } & \text { Las } \\
\text { Encartaciones } & \end{array}$ & Gatos monteses \\
\hline $\begin{array}{l}\text { Basque Country/ } \\
\text { Guipuzcoa At that } \\
\text { time part of Audiencia } \\
\text { Territorial de Burgos }\end{array}$ & Guipuzcoa province & Gatos monteses \\
\hline $\begin{array}{l}\text { Basque Country/ } \\
\text { Guipuzcoa. }\end{array}$ & Tolosa, Partido judicial & Gatos Monteses \\
\hline $\begin{array}{l}\text { Basque Country/ } \\
\text { Guipuzcoa }\end{array}$ & $\begin{array}{l}\text { Aldaba, } \\
\text { Guipuzcoa, }\end{array}$ & Gatos Monteses \\
\hline $\begin{array}{ll}\text { Basque } & \text { Country/ } \\
\text { Guipuzcoa } & \end{array}$ & Amasa & Gatos monteses \\
\hline $\begin{array}{ll}\text { Basque } & \text { Country/ } \\
\text { Vizcaya. At that time } \\
\text { Audiencia Territorial } \\
\text { de Burgos }\end{array}$ & Vizcaya province & Gatos monteses \\
\hline $\begin{array}{l}\text { Basque Country/ } \\
\text { Vizcaya }\end{array}$ & Orozco & $\begin{array}{l}\text { Gatos monteses } \\
\text { Tigres pequeños }\end{array}$ \\
\hline $\begin{array}{l}\text { Basque Country/ } \\
\text { Vizcaya/ Álava }\end{array}$ & $\begin{array}{l}\text { Sierra Gorbeya (At this } \\
\text { time at Burgos) }\end{array}$ & $\begin{array}{l}\text { Tigres pequeños } \\
\text { Onzas }\end{array}$ \\
\hline $\begin{array}{l}\text { Basque Country/ } \\
\text { Vizcaya }\end{array}$ & $\begin{array}{l}\text { Nanclares de Gamboa, } \\
\text { Vizcaya: }\end{array}$ & Linces \\
\hline $\begin{array}{l}\text { Basque Country/ } \\
\text { Vizcaya }\end{array}$ & Valmaseda, & Gatos monteses \\
\hline Cantabria/Santander & Valle de Cabuerniga & Gatos \\
\hline Cantabria/ Santander & Cosio & Gatos monteses \\
\hline Cantabria/ Santander & Arroyo, Reinosa & $\begin{array}{l}\text { gatos } \\
\text { monteses }\end{array}$ \\
\hline Cantabria/ Santander & Castro- Urdiales & Gatos monteses \\
\hline $\begin{array}{l}\text { Castille La Mancha/ } \\
\text { Albacete }\end{array}$ & $\begin{array}{l}\text { Albacete provincia } \\
\text { Sierra de Alcaraz y } \\
\text { Yeste }\end{array}$ & Gatos monteses \\
\hline $\begin{array}{l}\text { Castille La Mancha/ } \\
\text { Albacete }\end{array}$ & Chinchilla & Gatos monteses \\
\hline $\begin{array}{l}\text { Castille La Mancha/ } \\
\text { Toledo }\end{array}$ & Escalona & Gatos monteses \\
\hline $\begin{array}{l}\text { Castille La } \\
\text { Guadalajara }\end{array}$ & Moratilla de los Meleros & Gatos Monteses \\
\hline Castille La & Mota de Altarejos & Gatos Monteses \\
\hline
\end{tabular}

"Lynx sp. at Spain during XIXth Century. A case of study from..." 


\section{Cuenca}

Castille La Mancha/ Agudo, (Near Almadén) Gatos cervales Ciudad Real.

\begin{tabular}{|c|c|c|}
\hline $\begin{array}{l}\text { Castille La Mancha/ } \\
\text { Ciudad Real }\end{array}$ & $\begin{array}{l}\text { Almadén (Partido } \\
\text { Judicial) } \\
\text { Includes description of } \\
\text { Sierra Madrona. }\end{array}$ & Gatos Monteses \\
\hline $\begin{array}{l}\text { Castille La Mancha/ } \\
\text { Ciudad Real }\end{array}$ & Almadén (City) & Gatos monteses \\
\hline Castilla León/ Ávila & $\begin{array}{l}\text { Candeleda, Arenas de } \\
\text { San Pedro }\end{array}$ & Lobo cerval \\
\hline Castille Leon/ Soria & Espejon & Gatos monteses \\
\hline Catalonia/ Barcelona & Vich & Gatos monteses \\
\hline Catalonia/ Lerida & $\begin{array}{l}\text { Cogoll mont, near La } \\
\text { Seo de Urgell, } \\
\text { Castellciutat, Arabell, } \\
\text { Ballesta, Campmajor, } \\
\text { Anserall, Ars, } \\
\text { San Juan y Amurri }\end{array}$ & Gatos monteses \\
\hline Catalonia/ Girona & $\begin{array}{l}\text { Santa Coloma de } \\
\text { Farnes, }\end{array}$ & Gatos Monteses \\
\hline Catalonia/ Barcelona & $\begin{array}{ll}\text { Barcelona } & \text { Province. } \\
\text { Mountains } & \text { out of } \\
\text { Pyrenees. } & \end{array}$ & Gatos Monteses \\
\hline $\begin{array}{l}\text { Catalonia, Aragón, } \\
\text { Navarra. }\end{array}$ & Pirineos & Lince \\
\hline Extremadura/ Badajoz & Azuaga & $\begin{array}{l}\text { Gato cerval, parecido } \\
\text { al tigre. }\end{array}$ \\
\hline Extremadura/ Cáceres & Sierra de San Pedro & Lobo cerval \\
\hline Galicia/ Orense & Orense Provincia & Gatos Monteses \\
\hline Galicia/ Orense & Santa María de Casayo & Gatos Monteses \\
\hline Madrid/ Madrid & Tielmes & Gatos Monteses \\
\hline Navarra & $\begin{array}{l}\text { Larraona, Amescoa } \\
\text { Alta }\end{array}$ & Gatos monteses \\
\hline Navarra & Navarra (provincia) & $\begin{array}{l}\text { Lobos cerbales } \\
\text { Gatos Monteses }\end{array}$ \\
\hline Navarra & Arruazu. Araquil & Gatos monteses \\
\hline Navarra & Aoiz & Gatos Monteses \\
\hline
\end{tabular}




\begin{tabular}{lll}
\hline $\begin{array}{l}\text { Navarra } \\
\text { Rioja/ At that time } \\
\text { Logroño }\end{array}$ & $\begin{array}{l}\text { Aranache } \\
\begin{array}{l}\text { Valencian } \\
\text { Community/la } \\
\text { Castellón. }\end{array}\end{array}$ & Gatos monteses \\
$\begin{array}{l}\text { Valencian } \\
\text { community/Castellón }\end{array}$ & Arañuel & Gastellfort (Partidos monteses \\
$\begin{array}{l}\text { Valencian } \\
\text { Community/ Valencia }\end{array}$ & Sueca & Gatos cervales \\
$\begin{array}{l}\text { Valencian } \\
\text { community/Valencia }\end{array}$ & Millares & \\
$\begin{array}{l}\text { Valencian } \\
\text { community/ Valencia }\end{array}$ & Buñol & $\begin{array}{l}\text { Gatos ¿Silvestrese? } \\
\text { Posibly Wild cat. }\end{array}$ \\
\hline
\end{tabular}

"Lynx sp. at Spain during XIXth Century. A case of study from..." 
RIPARIA VOL. 6 (2020)

Table 4. Lynx referenced in an area where no references exist in towns or villages

\begin{tabular}{|c|c|c|c|}
\hline Province & $\begin{array}{l}\text { Reference } \\
\text { Madoz }\end{array}$ & Towns & $\begin{array}{l}\text { Reference in } \\
\text { town }\end{array}$ \\
\hline Navarra & $\begin{array}{l}\text { Lobos Cerbales } \\
\text { (Madoz) }\end{array}$ & $\begin{array}{l}\text { Aoiz, Arruazu. } \\
\text { Araquil, } \\
\text { Larraona, } \\
\text { Amescoa Alta }\end{array}$ & Gatos monteses \\
\hline \multirow[t]{2}{*}{ Pyrenees $^{124}$} & Lince (Madoz) & $\begin{array}{l}\text { Aragón } \\
\text { (Benabarre, } \\
\text { Castisaba, } \\
\text { Bacamorta, } \\
\text { Anzanigo) }\end{array}$ & Gatos monteses \\
\hline & & $\begin{array}{lr}\text { Catalonia } & \text { Santa } \\
\text { Coloma } & \text { de } \\
\text { Farnes, } & \text { Vich, } \\
\text { Cogoll mont, } \\
\text { near La Seo de } \\
\text { Urgell) }\end{array}$ & Gatos monteses \\
\hline
\end{tabular}

\begin{tabular}{llll} 
Malaga & $\begin{array}{l}\text { Gatos monteses } \\
\text { con } \\
\text { atigradas } \\
\text { pieles }\end{array}$ & Alfarnate & Gatos monteses \\
$\begin{array}{l}\text { (Madoz) } \\
\text { Partido judicial } \\
\text { Motril. }\end{array}$ & $\begin{array}{l}\text { Lince (Madoz) } \\
\text { Orense }\end{array}$ & $\begin{array}{l}\text { Los Tablones } \\
\text { Gatos monteses } \\
\text { (Madoz) }\end{array}$ & $\begin{array}{l}\text { Santa María de } \\
\text { Casaio } \\
\text { Sevilla }\end{array}$ \\
$\begin{array}{l}\text { Gatos monteses } \\
\text { Sadoz) }\end{array}$ & $\begin{array}{l}\text { Sanlúcar } \\
\text { Mayor, Écija }\end{array}$ & La & Gatos monteses \\
\hline
\end{tabular}

124 Navarra is part of Pyrenees but it have a particular reference. 
Table 5. References in Dictionaries of Royal Academy of Spanish Lenguage. Real Academia Española de la Lengua (RAEL)

\begin{tabular}{|c|c|c|}
\hline \multirow{2}{*}{$\begin{array}{l}\begin{array}{l}\text { Word referenced } \\
\text { (translated if possible) }\end{array} \\
\text { Gato Clavo ("Pin" cat) }\end{array}$} & Text (Translated) & Reference/ year \\
\hline & "kin of Gato Montés" & RAEL 1803 \\
\hline & $\begin{array}{l}\text { "Also called Serval cat. } \\
\text { Kind of cat which tail is } \\
\text { near } 35 \mathrm{~cm} \text { long. It has } \\
\text { wide head with long hair } \\
\text { around the face. Soft, } \\
\text { grey, short fur, with a lot } \\
\text { of black spots which } \\
\text { bécame ring at the tail. It } \\
\text { lives at central and } \\
\text { southern Spain. It climbs } \\
\text { the tres and is a danger } \\
\text { vermin. Fur is valuable } \\
\text { for clothes. }\end{array}$ & RAEL 1914 \\
\hline Tigre. Tiger (Jaguar) & $\begin{array}{l}\text { "cuadruped, cat shaped, } \\
\text { much bigger and faster } \\
\text { than it. Lyon like claws, } \\
\text { long tail, yellow eyes, } \\
\text { great mandibles. It fur is } \\
\text { full of different colour } \\
\text { spots. }\end{array}$ & $\begin{array}{l}\text { All dictionaries RAEL } \\
\text { from XVIIIth/ XIXth } \\
\text { century but } 1899 \\
\text { dictionary. From } \\
\text { 1898, Tiger is used for } \\
\text { Panthera tigris, not } \\
\text { for Jaguar. }\end{array}$ \\
\hline $\begin{array}{l}\text { Lobo cerval (deer } \\
\text { wolf) }\end{array}$ & $\begin{array}{l}\text { "Very dangerous vermin" } \\
\text { "good sigh" "spotted } \\
\text { skin beast" } \\
\text { "Also called Lynx. It's } \\
\text { called Wolf but it seems } \\
\text { more like a cat" "spotted } \\
\text { skin beast" }\end{array}$ & RAEL 1729 \\
\hline Lynx & $\begin{array}{l}\text { "quadruped animal also } \\
\text { called lobo cerbal. It's } \\
\text { not as strong as a wolf } \\
\text { but it a few similar. It fur } \\
\text { looks like Tiger fur } \\
\text { because it is full of spots. } \\
\text { It has a great sawn. } \\
\text { Lynx" }\end{array}$ & RAEL 1780 \\
\hline $\begin{array}{l}\text { Gato Montés (Wild } \\
\text { cat) }\end{array}$ & $\begin{array}{l}\text { A "kind" of gato montés } \\
\text { is Gato Clavo ("Pin" cat) }\end{array}$ & RAEL 1803 \\
\hline
\end{tabular}

"Lynx sp. at Spain during XIXth Century. A case of study from..." 
RIPARIA VOL. 6 (2020)

Table 6: Holocene records of lynx (Lynx spp.) in archaeological sites from the northern region of the Iberian Peninsula.

\begin{tabular}{|c|c|c|c|}
\hline $\begin{array}{l}\text { Species } \\
\text { morfometric } \\
\text { classification* }\end{array}$ & $\begin{array}{l}\text { Molecular } \\
\text { identification }\end{array}$ & Site & $\begin{array}{l}\text { Aprox age of } \\
\text { the lynx } \\
\text { remains }\end{array}$ \\
\hline $\operatorname{Lyn} x \operatorname{lyn} x$ & $\operatorname{Lyn} x \operatorname{lyn} x$ & $\begin{array}{l}\text { Sima Pagolusieta (Vizcaya, } \\
\text { Spain) }\end{array}$ & Holocene \\
\hline $\operatorname{Lyn} x \operatorname{lyn} x$ & Lynx pardinus & Urratxa III (Vizcaya, Spain) & NA \\
\hline NA & $\operatorname{Lyn} x \operatorname{lyn} x$ & Serpenteko (Navarra, Spain) & Holocene \\
\hline NA & $\operatorname{Lyn} x \operatorname{lyn} x$ & $\begin{array}{l}\begin{array}{l}\text { Cueva de los } \\
\text { (Asturias, Spainchos }\end{array} \\
\end{array}$ & Holocene \\
\hline NA & $\operatorname{Lyn} x \operatorname{lyn} x$ & $\begin{array}{lll}\text { Pozu’l Lince } & \text { (Asturias, } \\
\text { Spain) } & & \\
\end{array}$ & Holocene \\
\hline $\operatorname{Lyn} x \operatorname{ly} n x$ & NA & $\begin{array}{ll}\text { Santimamiñe } \\
\text { Spain) }\end{array}$ & \begin{tabular}{|l|} 
Holocene \& \\
Pleistocene \\
\end{tabular} \\
\hline Felis lynx & NA & Las Pajucas (Vizcaya, Spain) & Holocene \\
\hline Lynx pardinus & Lynx pardinus & Chaves (Huesca, Spain) & $\begin{array}{l}\text { Holocene \& } \\
\text { Pleistocene }\end{array}$ \\
\hline Lynxpardinus & Lynx pardinus & Portalón (Burgos, Spain) & Holocene \\
\hline Lynx pardinus & Lynx pardinus & $\begin{array}{l}\text { Peña del Moro (Barcelona, } \\
\text { Spain) }\end{array}$ & Holocene \\
\hline Lynx sp. & NA & Marguineda (Andorra) & Holocene \\
\hline L. pardinus & NA & $\begin{array}{l}\text { Balma de l'Espluga (Gerona, } \\
\text { Spain) }\end{array}$ & Holocene \\
\hline L. pardinus & NA & \begin{tabular}{ll|} 
Can Sadurní (Barcelona, \\
Spain)
\end{tabular} & Holocene \\
\hline Lynx sp. & NA & \begin{tabular}{|l|l|}
$\begin{array}{l}\text { Cova de Bolet (Barcelona, } \\
\text { Spain) }\end{array}$ & \\
\end{tabular} & Holocene \\
\hline Lynx cf. spelaeus & NA & $\begin{array}{lll}\text { Cova Verda } & \text { (Barcelona, } \\
\text { Spain) } & & \\
\end{array}$ & Holocene \\
\hline Lyns sp. & NA & Parco (Lérida, Spain) & Holocene \\
\hline $\operatorname{Lyn} x \operatorname{lyn} x$ & NA & $\begin{array}{l}\text { col d'Aran (Pyrenees, } \\
\text { France) }\end{array}$ & Holocene \\
\hline Lynx $\operatorname{lyn} x$ & NA & Schatzi (Pyrenees, France) & Holocene \\
\hline Lynx byn & NA & Péne (Pyrenees, France) & Holocene \\
\hline $\operatorname{Lyn} x \operatorname{ly} n x$ & NA & Montfort (Pyrenees, France) & $\begin{array}{l}\text { Holocene \& } \\
\text { Pleistocene }\end{array}$ \\
\hline
\end{tabular}


A. VILLALPANDO MORENO

\begin{tabular}{|c|c|c|c|}
\hline $\begin{array}{l}\text { Species } \\
\text { morfometric } \\
\text { classification* }\end{array}$ & $\begin{array}{l}\text { Molecular } \\
\text { identification }\end{array}$ & Site & $\begin{array}{l}\text { Aprox age of } \\
\text { the lynx } \\
\text { remains }\end{array}$ \\
\hline $\begin{array}{l}\text { Lynx } \\
\text { spelaeus? }\end{array}$ & NA & $\begin{array}{l}\text { Montmaurin (Pyrenees, } \\
\text { France) }\end{array}$ & $\begin{array}{l}\begin{array}{l}\text { Pleistocene } / \mathrm{H} \\
\text { olocene }\end{array} \\
\end{array}$ \\
\hline Lynx cf. spelaeus & NA & $\begin{array}{ll}\text { Lombrives } & \text { (Pyrenees, } \\
\text { France) } & \\
\end{array}$ & NA \\
\hline Lynx sp. & NA & (Pyrenees, & \begin{tabular}{|l} 
Holocene \& \\
Pleistocene \\
\end{tabular} \\
\hline Lynx sp. & NA & Élèphant (Pyrenees, France) & $\begin{array}{l}\text { Holocene \& } \\
\text { Pleistocene }\end{array}$ \\
\hline Lynx sp. & NA & $\begin{array}{l}\text { Mas-dÁzil } \\
\text { France) }\end{array}$ & \begin{tabular}{|l|} 
Holocene \& \\
Pleistocene \\
\end{tabular} \\
\hline Lynx cf. spelaeus & NA & $\begin{array}{l}\text { La Tute de } \text { Carrelore } \\
\text { (Pyrenees, France) }\end{array}$ & Holocene \\
\hline
\end{tabular}

"Lynx sp. at Spain during XIXth Century. A case of study from..." 


\section{Bibliography}

AAVV, Vocabulario Castellano- Gallego de las Irmandades de Fala, Primera edición, Imp. Moret. La Coruña, 1933

AA.VV. Memorial literario o Biblioteca periodica de Ciencias, Literatura y Artes. 06/1804, No 46, año 4, Madrid, Imprenta de Vega y C $C^{\text {a }} 1804$.

AA.VV. Revista de Andalucía. Año II. Tomo III, A.L. CARrión (Dir), Málaga, 1875.

AA.VV. Revista Gaditana. Periódico popular, No 13, 01/26/1840, Imprenta de Esteban Picardo, Cádiz.

J. ACOSTA, Historia natural y moral de las Indias, en que se trata las cosas notables del cielo, elementos, metales, plantas y animales dellas y los ritos $y$ ceremonias, leyes, govierno y guerras de los indios. Madrid 1590

M. Alonso VALladARES \& J. A. GARRido GARCíA, La explotación de los recursos cárnicos en la frontera del Reino Nazarí de Granada: un estudio de caso en el yacimiento de La Moraleda (Antequera, Málaga), Revista del Centro de Estudios Históricos de Granada y su Reino 27, 2015, 21 39.

M. Altamirano García, Not only bones. Hard animal tissues as a source of raw material in 3rd millenium BC south-eastern Iberia, Menga: Revista de prehistoria de Andalucía, No 5, 2014, 43-67.

F. Botello, P. Illoldi-RANGel, M. Linaje \& V. SÁNCHEZCORDERO. Primer registro del tigrillo (Leopardus wiedii, Schinz 1821) y del gato montés (Lynx rufus, Kerr 1792) en la Reserva de la Biosfera de Tehuacán-Cuicatlán, Oaxaca, México, Acta Zoológica Mexicana, 22(1), 2006, 135-139.

J. BOY, Diccionario teórico, práctico, histórico y geográfico de comercio. Tomo III, publicado bajo los auspicios de la M.I. Junta de Comercio de Barcelona, Imp. Valentín Torrás, Barcelona, 1840.

J.B. BRÚ, Tomo I de la Colección de Animales y Monstruos del Real Gabinete de Historia Natural de Madrid, Madrid, 1784.

J. CABALlERO SOLER, Fauna vertebrada de la provincia de Ciudad Real en el s. XX. Estudio comparativo de la obra "Catálogo sistemático de exposición faunistica de la Provincia de Ciudad Real", Asociación cultural La Carrahila, 2017. 
A. CABrera, Fauna Ibérica. Mamiferos. Junta para ampliación de estudios e investigaciones cientificas, Museo Nacional de Ciencias Naturales, About Lince, Madrid, 1914.

J.S. Carrión, C. Finlayson, S. Fernández, G. Finlayson, E. AlluÉ, J.A. LÓPEZ-SÁEZ \& P. GONZÁlEZ-SAMPÉRIZ, A coastal reservoir of biodiversity for Upper Pleistocene human populations: palaeoecological investigations in Gorham's Cave (Gibraltar) in the context of the Iberian Peninsula, Quaternary Science Reviews 27 (23-24), 2008, 2118-2135.

M. Casas-Marce, E. Revilla, M. Fernandes, A. Rodríguez, M. DelibeS, J.A. GODOY, The Value of Hidden Scientific Resources: Preserved Animal Specimens from Private Collections and Small Museums, Bioscience 62 (12), 2012, 1077-1082.

J.B. CASSOLA, Ensayo histórico sobre la antigüedad, honores y privilegios de la muy noble y leal ciudad de Baza y pueblos de su abadía, Imprenta de P. Flores, Baza, 1855.

A. CASTElls \& M. MAYO, Guía de los mamiferos en libertad de España y Portugal, Ed. Pirámide, Madrid, 1993.

M. Clavero, M. DeliBeS, Using historical accounts to set conservation baselines: the case of Lynx species in Spain, Biodiversity and conservation, vol. 22, no 8, 2013, 1691-1702.

F.J. Clavijero, Historia Antigua de México, México 1891, (1756).

A.P. Clevenger, Observación de un lince ibérico (Lynx pardinus) en la provincia de Lugo, norte de España. Doñana, Acta Vertebrata 14, 1987, 140-142.

Collantes de Teran. Historia de Morón de la Frontera. Biblioteca de Estudios Moronenses, 1, A.M. BERNAL, M. GARCÍA FERNÁNDEZ (Eds), Fundación Fernando Villalón, Morón de la Frontera, 1990, (1840).

L. COMPANY, Histoire naturelle dy dèpartement des pyrénèes-orientales, T.3, Imp. Alzine, Perpignan, 1863.

S.E. COOK, Sketches in Spain during de years 1829, 30, 31, 32, Vol. II, 1834.

S. COVARRUBiAs, Tesoro de la lengua castellana o española, Imprenta Luís Sánchez, Madrid, 1611.

"Lynx sp. at Spain during XIXth Century. A case of study from..." 
A. Chapman, W.J. BuCK, La España Inexplorada, Junta de Andalucía, Sevilla, 1989, (1910).

M. DELIBES DE CASTRO, El lince ibérico: ecología y comportamiento alimenticios en el Coto Doñana, Doñana. Acta vertebrata, Volumen 7, Consejo Superior de Investigaciones Científicas. Estación Biológica de Doñana, Sevilla 1980

M. Delibes, A. Rodriguez and P. Ferreras, Action Plan for the Conservation of the iberian Lynx. (Lynx pardinus) in Europe, Bern Convention, Nature and Environment, Council of Europe Publishing, $\mathrm{n}^{\circ}$ 111, 2000, 18

D.G. ELLIOT, A monograph of the Felida or the Family of Cats, Imp. Taylor \& Francis, London, 1883.

G. FERNÁNDEZ DE OVIEDO, Historia general y natural de las Indias, islas y Tierra Firme del mar Océano. Enriquecida por José Amador de los Ríos. Ed. Real Academia de la Historia, Madrid 1852, (1535).

FERnÁndez SONGEL, Revista Técnica de la Guardia Civil. Caza: Ley, reglamento y disposiciones oficiales dictadas hasta el dia, relativas a la caza. Recopilación anotada y comentada por el capitán Fernández Songel, Año II, N ${ }^{\circ}$ 19, Julio de 1911. Dirección, Redacción y Administración, Calle de Churruca no 15, Madrid 1911

J.M. Fernández, N. Ruiz dE AZuA, C. Tejado, Notas históricas sobre algunas especies faunísticas, J.M. FERNÁNDEZ (coord.), Estudio faunistico del Parque Natural de Gorbeia. Fauna de Vertebrados excepto quirópteros, Diputación Foral de Navarra, 2003, 33-92.

O. García Puchol, F. Cotino Villa, C. Miret Estruch, Ll.J. pascual Benito, S.B. McClure, L. Molina Balaguer \& B. Culleton, Cavidades de uso funerario durante el Neolítico final/Calcolítico en el territorio valenciano: trabajos arqueológicos en Avenc dels Dos Forats o Cova del Monedero (Carcaixent, Valencia), Archivo de Prehistoria Levantina 28, 2010.

G. Garrote, G. López, J.M. Gil, E. Rojas, M. Ruiz, J. Bueno, S. Lillo, J. Rodriguez-Siles, J. Martín, J. PÉReZ, M. GArciaTARDio, G. VAlenzuela, M. Simon, Human-felid conflict as a 
further handicap to the conservation of the critically endangered Iberian lynx, European Journal of Wildlife Research, 2013.

F. GragerA DiAZ, Distribución histórica del lince ibérico en Extremadura, Quercus 174, 2000, 42-45.

M. GRANADOS CORONA, Transformaciones históricas del parque nacional de Doñana, Depósito Universidad de Sevilla, Tesis Doctoral inédita, Universidad de Sevilla, 1987, https://idus.us.es/handle/11441/48253

V. GutiÉrREZ AlBA, Apuntes históricos sobre el lince ibérico en Andalucía, Galemys 19 (2), 2007, 33-52.

E. Halna-Klein, Sur les traces du Lynx, Rev. Etudes Médiévales 28, 1995, 119-128.

J. Jiménez, M. Clavero, A. Reig-Ferrer, New old news on the "Lobo cerval" (Lynx lynx?) in NE Spain/Nuevas referencias antiguas sobre el lobo cerval (¿Lynx lynx?) en el NE de España, Galemys, 30, 2018, 31-36.

C.A. LÓPEZ-GonzÁlez, D. ÁvilA-Aguilar \& M.F. CruZ-TorreS, Abundancia del gato montés (Lynx rufus escuinapae JA Allen, 1903) en el Parque Nacional el Cimatario, Querétaro, México, Acta zoológica mexicana, 31(1), 2015, 138-140.

V. Lopez SeOAnE, Fauna Mastológica de Galicia o historia natural de los mamiferos de este antiguo reino., aplicada a la medicina, a la agricultura, a la industria, a las artes y el comercio, Imprenta de Manuel Mirás, Santiago 1861

P. Madoz, Diccionario Geográfico- Estadístico- Histórico de España y sus posesiones de ultramar, Imp. Madoz y Sagasti, Madrid 1845.

J. MALUQUer i Sostres, Noticia de la fauna de Catalunya i dÁndorra al final del segle XVIII, Butlletí de la Institució Catalana d'Història Natural 60, 1992 (Secció de Zoologia, 9), 5-21.

L. MARTíneZ y Reguera, Fauna de Sierra Morena. Catalogo descriptivo de los mamiferos del término de Montoro, con la indicación de las utilidades y perjuicios que pueden producir al hombre, Imp. Romero Rodríguez, Madrid 1881.

S. Miñano y BeDOYA, Diccionario Geográfico y Estadístico de España y Portugal, Im. Pierad - Peralta, Madrid 1826.

"Lynx sp. at Spain during XIXth Century. A case of study from..." 
A. Molinier, N. Molinier-Meyer, Environment et Historie: les loups et l'homme en France, Revue d'bistorie moderne et contemporaine 28, $\mathrm{N}^{\circ}$ 2, Avril-juin, 1981, 225-245.

G. MONFORT, Retrato de una tierra salvaje. (Portrait of a wilderness) La historia de las expediciones al Coto de Doñana, Ilustrado por Eric Hosking, Introducción del Mariscal de Campo Vizconde Alanbrooke, Diputación de Sevilla, Re-ed. 1994, (1954).

P. Monserrat ReCOVER, Estado Actual de los studios sobre flora de Aragón, Flora y fauna aragonesas, II Jornadas sobre el estado actual de los estudios sobre Aragón. Huesca, 19-21 Diciembre 1979. Vol. II, Zaragoza 1980, 879-896.

E. NAVAS, J.A. EsquiVEL, F. MOLINA, Butchering patterns and spatial distribution of faunal animal remains consumed at the Los Millares chalcolithic settlement (Santa Fe de Mondújar, Almería, Spain), Oxford Journal of Archaeology, 27 (4), 2008, 325-339.

C. NORES, ¿Es el lobo cerval un lince boreal (Lynx lynx)?, IV Jornadas Españolas de Conservación y Estudio de Mamiferos. Libro de resúmenes, Sociedad Española de Conservación y Estudio de Mamíferos, Segovia 1999.

C. Nores, V.M. VÁZqueZ, Datos sobre la presencia del lince en Asturias desde el s. XVIII, Acta Biologica Montana 4, 1984, 361-370.

J.L. PASCUAL Benito, Industria ósea sobre huesos y dientes de lince en la prehistoria de la Península Ibérica, Interaccions entre felins $i$ bumans: homenatge a Innocenci Sarrión Montañana, Museu de Prehistòria de València, 2017, 189-212.

J. PIÑEIRO MACEIRAS, El lobo cerval: notas etnográficas, Argutorio: revista de la Asociación Cultural "Monte Irago", 16 (30), 2013, 16-20.

ReAl ACADEmia EsPañola De la LenGuA, Diccionario de la lengua castellana en la que se explica el verdadero sentido de las voces, su naturaleza y calidad, con las frases o modos de hablar, y otros proverbios y refranes y otras cosas convenientes al uso de la lengua, Tomo IV (G-N), Imprenta herederos de Francisco Hierro, Madrid, 1734. 
REAL ACADEMIA Española DE LA LENGUA, Diccionario de la Lengua Castellana, compuesto por la Real Academia Española, reducido a un tomo, Imprenta Viuda de Ibarra, Madrid 1803.

ReAl ACADEmia EsPañola DE LA LENGUA, Diccionario de la lengua castellana por la Real Academia Española, Imprenta Real, Madrid 1817.

ReAl ACADEMIA DE la Historia, Diccionario Geográfico Histórico de España, por la Real Academia de la Historia, Imp. Academia, Madrid 1802.

R. Rodríguez -VArela, N. García, C. Nores, D. AlvareZ-LaO, R. BARnetT, J.L. ArsuagA, C. VAldiosera, Ancient DNA reveals past existence of Eurasian lynx in Spain, Journal of Zoology 298, 2, 2016, 94102.

M.A. SALAS PÁEZ, Hábitos alimenticios de la zorra, coyote y gato montés en la Sierra Tarasca, Revista Mexicana de Ciencias Forestales, 12 (62), 2012.

M.C. SAINT GIRONS, Report sur la Disparition du Lynx en France, J. KRATOCHVIL (ED.), History of the distribution of the Lynx in Europe, Prirodovedné prace ustavú Ceskoslovenské akademie vëd Brne. Acta sc. Nat. Brno 2 (4), 1968, 1-50.

R. SÁNCHEZ, Una cacería en el Coto de Oñana, publicada por Juan Perez de Guzman y Bouza, Guillermo Vázquez (Ed.), Madrid 1984, (1841).

J.P. TORRENTE \& L. LLANEZA RODRÍGUEZ, Sobre'l llobu cerval y la so presencia n'Asturies, Asturies: Memoria encesa d'un país 2, 1996, 81-86.

J.A. VALVERDE, Información sobre el Lince en España, Boletín técnico. Serie cinegética, $N^{\circ} 1$, Ministerio de Agricultura, Servicio general de Montes, Caza y Pesca fluvial, Impr. Rotaprint, 1963.

C. ZALDÍvAr EzQUERro \& J. L. GÓMEZ dE FranCisCO, Apuntes para la desdichada historia del oso, la cabra montés y el lince en La Rioja, Belezos: Revista de cultura popular y tradiciones de La Rioja 6, 2008, 44-49.

J.B. Zofío \& I. VeGA, I. (Eds.), El Línce Ibérico, Editorial Debate / WWF- ADENA, Madrid, 2000.

"Lynx sp. at Spain during XIXth Century. A case of study from..." 